\title{
Violent crime and extremism in South Sudan: The modus operandi of organised criminal groups and political corruption
}

Dau Ding ( $\square$ daucoldau@doctors.org.uk)

University of Leicester https://orcid.org/0000-0003-2197-6793

Article

Keywords: Criminology, Group Identity, Forensic Psychology, Terrorism, Democracy, Africa

Posted Date: June 17th, 2021

DOl: https://doi.org/10.21203/rs.3.rs-520854/v1

License: () (1) This work is licensed under a Creative Commons Attribution 4.0 International License. Read Full License 


\section{Abstract}

Environmental Criminology (EC) theories are regularly employed by law enforcement practitioners within their efforts to disrupt the criminal activities of motivated offenders. However, EC theories have not been utilised to combat the illicit activities of "State-supported" offenders. This study explored organised crime in South Sudan by applying EC theories and large group population psychoanalysis. A null hypothesis - "violent crime in South Sudan is not associated with ideological extremism" - was postulated and assessed. Fifty-Four South Sudanese government officials participated in semi-structured interviews. Violent crime and organised crime were reported to be common in South Sudan. Both were identified as being facilitated by political corruption. The study concludes that there is no association between ideological extremism and violent crime; including ethnic and tribal extremism. EC theories and population psychoanalysis may be cogently employed to practically inform stakeholders' efforts in combating the criminal activities of State-supported motivated offenders. The EC crime triangle is a useful tool for highlighting State-supported illicit activities that: Challenge democratic governance in failing or failed Nation-States; Undermine the international rules of law and human rights, and; Threaten global peace and security via transnational criminal activities, including the financing of foreign terrorist organisations.

\section{Introduction}

The association between organised crime and political corruption has been studied extensively by several authors (Fleischacker, 2018; Gouney \& Bezlov, 2013; Van Duyne, 1996). Some have concluded that the association is direct. However for this to transcend into more sustained and organised criminal activity, it has necessitated some element of sophistication and coordination within the jurisdiction in question. Without there being some protective component within the domestic criminal justice system architectures in operation, it would make its organised and perpetually criminal nature more difficult to maintain. What makes the link between political corruption and organised crime in Africa far more of a concern than in more developed and durable economies, is the lack of any transparent oversight mechanisms nor the lack of desire to circumvent its impact on the lives of the general population. The complicity between government and organised criminal groups becomes intractable to address (Mailey, 2015). Ultimately, the concept of corruption becomes accepted as part of the "normal way of life" for many Africans in their countries (Acemoglu \& Verdier, 2003; Kostakos, 2018; Sparling, 2017; Tambulasi, 2009). Corruption is not just reserved to the theft of public funds. It transcends into more violent criminal behaviours such as premeditated murder and terrorism (Sahgal \& Zeuthen, 2020). Violent criminal behaviours that occur within the backdrop of a selectively effective criminal justice system (Marion, 2008). Without there being a significant element of fear of accountability for the perpetrators of crimes, trust in law and order from the victims of crime is significantly diminished. The political corruption and its resulting impunity destroys the cohesive fabric of society; and it ultimately leads to a scenario of failure of State craft as the civilian population feels helpless in curtailing their real and their perceived existential threats. The resultant longterm damage imparted upon any criminal justice system's structures and its capacity to deliver accountability for crimes that are committed, is significant (Deng, Lopez, Pritchard, \& Ng, 2015). This study shall explore the case of South Sudan and the country's association with organised criminal behaviours and illicit activities.

\subsection{Failure of State Formation in South Sudan}

South Sudan came into existence as a new and sovereign country on 9 July, 2011. It seceded from the Sudan following a popular referendum (Johnson, 2011; Johnson, 2016). This was a process that took over 50 years since the Sudan gained its independence from its former colonial British and Egyptian rulers. Sudan was the first country in Africa to gain its independence in 1956. Following decades of a post-independence civil war - with a hiatus of an intermittent peace process in the 1970s which led to some governance stability and development in the then southern Sudan, including the instituting of an organised law enforcement and criminal justice system - a second civil war erupted in 1983. This second civil war ultimately led to southern Sudan's independence in 2011 under the auspices of the "Sudan Peoples Liberation Army" (SPLA); and its political wing, the "Sudan People's Liberation Movement" (SPLM). The second Sudan civil war was notable for its violent and other illicit activities on all sides of the conflict. Illicit activities which many observers labelled as war crimes (De Waal, 2014). Yet within the spectre of a fight for freedom from a common enemy, accountability for these crimes was ignored and overlooked. The lack of accountability still remains. Consequently, and since independence, violent and criminal behaviours have become commonplace within the new country of South Sudan's fledgling governance structures (Branch \& Mampilly, 2005; DFID, 2018; FinCEN, 2017; FinCEN, 2018; NECC, 2020). Additionally, the propensity for political corruption and organised criminal activities to co-exist has increased. Several observers argue that it has worsened since South Sudan's independence (Checchi, Testa, Warsame, Le, \& Burns, 2018; Craze, 2020; Madut, 2020; Rolandsen, 2015; The Sentry, 2016; The Sentry, 2020; Young, 2021). South Sudan is now considered to be a de facto "failed State". A country whose governance and socioeconomic indicators stand at the bottom of global rankings within most independent reviews conducted annually (FSI, 2020). With this asserted mal-governance, a Hobbesian state of existence has developed in the new country which is reflective of the society's loss of trust in the rule of law and order (Dietz, 1990). As a consequence of decades of war, human displacement from their homes, poverty and death, this has been further compounded by a ubiquitous state of "societal regression" amongst the majority of the population (Tutlam et al., 2020; Volkan, 2004). With such a high degree of social regression, this may become malignant (violent) where the population reverts to a more feral form of survival (Eifert, Miguel, \& Posner, 2010; Justin \& De Vries, 2017; Volkan, 2006). The reliance on a larger collective group's identity which is usually ethnocentric or religious in its predisposition, becomes a personal means of physical protection and socioeconomic maintenance (Bovenkerk Siegel, \& Zaitch, 2003). This societal regression aligned with failed and corrupted governance structures where criminal activities go unpunished, have been considered to be the concomitant drivers of civil conflict within South Sudan. The association between malignant societal regression, political corruption and organised crime being exemplified by selective justice for crimes that are regularly perpetrated against law-abiding individuals (Schomerus \& Rigterink, 2016).

\subsection{Political Corruption}

The level of corruption in South Sudan has been regularly reported since the new country's independence; with some authors stating that it began immediately after the then unified country of Sudan signed its Comprehensive Peace Agreement in January 2005 to end its second civil war (De Waal, 2014). 
The broad and commonly accepted definition for political corruption is: "The use of powers by government officials and their networks to partake in illegitimate or illicit activities for personal gain and gratification." Political corruption exists in most countries in the world, and it manifests itself in different forms (Navot, 2016). Within Africa as a continent, the concept is one of the most debilitating and limiting for genuine socioeconomic growth and development for most of its citizens. To attempt to appreciate the nature of the impact that it has had on the daily lives of the vast majority of people, one merely needs to observe how difficult it has been to root out for decades not just for domestic political actors and civil society activists, but also for the larger international community stakeholders and its various multi-lateral organisations (Warren, 2004). Alongside the use of violence and fear, organised crime is significantly assisted by corruption for its continuing presence. Corruption expedites organised crime's perpetual operational activities. It leads to the flouting of the rule of law wherever it is present. In countries where organised crime has a significant presence, law enforcement investigations into crimes are invariably obstructed by corruption within the political and/or the criminal justice system (Van Dijk, 2007). For every corrupter there must be at least one person who has been corrupted. Law enforcement agents and public officials are regularly sought-out to be corrupted by organised crime groups and their networks. Once an individual has been corrupted, they will invariably be corruptible again in the future. They will have left themselves open and vulnerable to blackmail and exposure if they refuse to cooperate. Corruption is founded globally on the basis that most organised criminal activities are now transnational; and South Sudan is no exception. Without corruption across international borders to facilitate any illicit network's activities, the continuous criminal enterprise would not function as well - nor as profitably - as it does.

\subsection{Organised Criminal Groups and Networks}

The definition of "organised crime" can be as numerous and varied as the number of law enforcement practitioners that are engaged with the subject. The United Nations' Centre for International Crime Prevention broadly considers organised crime as a structured criminal activity that is regularly engaged-in by individuals within a group, or several groups, and it invariably involves violence within its profit-driven motivation (UNODC, 2004).

For a natural resources' rich country whose population has a literacy rate of only $27 \%$, South Sudan has been a free-market economy since before its secession (UNESCO, 2020).This, aligned with the free and unmonitored influx of foreign investors from dubious locales, has permitted the country to become a safe haven for groups of individuals that wish to partake in domestic and cross-border illicit activities. An illicit black market economy that is associated with sociopolitical rent-seeking and graft now flourishes in the new country (The Sentry, 2019).

Organised crime emerges wherever there is an absence of strong and legitimate governance and State control. A Nation-State which even partly fails to safeguard the life and the property of its citizens, mislays its credibility and legitimacy, and it opens itself up to illicit elements and groups filling the vacant sociopolitical governance vacuum (Varese, 2001). Organised crime has many dimensions and can manifest itself in different forms. All of which are driven by profit-making enterprises. South Sudan is not an exception. It is a multi-billion US Dollar business annually; and it operates in almost every country in the world reflecting its transnational nature and inter-connectedness. Organised criminal groups are not limited in the offences that they are willing to commit in their search for profit-making enterprises. As long as money can be generated from the activity, the group and its network will engage in the illicit activity. Consequently, the in-exhaustive list of crimes that organised criminal groups are willing to engage in include: Racketeering; fraud and money-laundering; extortion; bribery and corruption; robbery; kidnapping; gambling; goods 'and drugs 'smuggling and trafficking; prostitution and human trafficking and people smuggling; arms dealing, and; murder (Siegel \& Nelen, 2008). As long as there is a profitable market and demand for the product or service being illegally provided, the organised criminal group's activities will adapt to supply and meet that demand in exchange for considerable profits.

The term "organised crime" has been diversely defined and described. However, the complete definition and description that best befits in the context of this study is that it is: "A non-ideological enterprise that involves a number of persons in close social interaction, organised on a hierarchical basis, for the purpose of securing profit and power by engaging in both illegal and legal activities which yield high profits while offering relatively low risks. Positions may be assigned on the basis of kinship, or rationally assigned according to the skill. The positions are continuous and not dependent on the individuals occupying them at any particular time. Permanency is assumed by the members who strive to keep the enterprise integral and active in pursuit of its goals. It eschews competition and strives for monopoly over particular activities on an industry or territorial basis. There is a willingness to use actual or threatened violence, fear and/or bribery and corruption of public officials, graft and extortion to achieve ends or to maintain discipline. Membership is restricted, although nonmembers are involved on a contingency basis. The impact of the group's activities is significant upon the people in their locales, region or country as a whole. Organised crime is a continuing criminal conspiracy with an organised structure that is successful because of its use of fear, corruption and violence" (Lebeya, 2012; Mallory, 2012; Woodiwiss, 1999).

\subsection{Environmental Criminology}

To attempt to scientifically understand the criminal behaviours of individuals and the motivations behind them, Environmental Criminology Theories (ECT) have been circumscribed. Routine Activity Theory (RAT) and Rational Choice Theory (RCT) - with Crime Patten Theory (CPT) which is encompassed by the principles of RCT - along with the recent theory of Cultural Criminology (CC), have been hypothesised (Andresen \& Farrell, 2015; Brantingham, Brantingham, Song, \& Spicer, 2018). In employing these theories, law enforcement practitioners are able to determine what motivates not just a "motivated offender" to partake in illicit activities, but also what motivates the other individuals within the "significant individual of interest's" group and network to participate (Bruinsma \& Johnson, 2018; Cullen \& Kulig, 2018). In the case of South Sudan, this study shall focus on the current Head of State and President of the country, Salva Kiir Mayardit, as a significant individual of interest who is at the centre of a larger organised group called the Sudan People's Liberation Movement (SPLM). The SPLM has remained as the ruling political party of South Sudan since independence. It is alleged to be associated with both domestic and international criminal elements. Salva Kiir has been identified as "the leader" of this SPLM "organised group" since August 2005. Environmental criminology focuses on the influences of the personal environment and situational factors in facilitating the criminal activities undertaken by individuals. Alongside RAT, environmental criminology incorporates RCT and CPT; together with Situational Crime Prevention. RAT encompasses all of these concepts, and together they prove useful for understanding crime as a situational event for the purposes of crime solving and crime prevention. Another more 
contemporary criminology theory, CC, contrasts the ECT. Rather than rationality, and offenders knowing exactly what they are doing when partaking in criminal behaviours, $\mathrm{CC}$ focuses more on the role of irrational human emotions as the basis for criminal behaviour and intent (Lilly et al, 2015).

\subsubsection{Rational Choice Theory}

RCT is a concept that is based on the understanding that people make voluntary calculations on how they want to act and behave. It states that all behaviour is motivated by a particular individual's own decisions; decisions that are geared towards the pursuit of happiness and an avoidance of displeasure. This theory aims to provide an insight into why individual offenders decide to commit certain crimes - which is rooted in their desire to attain rewards and selfsatisfaction - and that individual offenders are personally responsible for the criminal behavior choices that they make. Consequently, criminal behaviours can be curtailed by a fear of punishment; one of the mainstays of modern crime deterrent policies for specific crimes. Before committing a crime, an offender weighs up the pros and cons of getting caught, the severity of the expected penalty if they get caught, and the benefit to be gained by committing the criminal act. So if the cost of getting caught is perceived to be high or the benefit gained is small, the individual will tend to opt not to partake in the criminal act. Personal factors (e.g., the need for money, looking for revenge, or simply "just for the thrill and fun of it") along with situational factors - the vulnerability of the target or the victim, and the absence of any protective guardian at the target - determine the opportunity for a "motivated offender" to commit a crime. All of these factors are the basis of situational crime prevention which is grounded in rational choice theory.

\subsubsection{Routine Activities Theory}

RAT compliments RCT, and it is founded upon three steps:

1. That there is a "motivated offender" with the intent to commit a crime;

2. That there is a "target" that the motivated offender sees as attractive, and;

3. That there is nothing protecting that target that concerns the motivated offender to be able to commit their crime; there is "no capable guardian".

All of these three steps must exist at the same time for a crime to be committed.

This theory provides an insight into how changes in an individual's social and economic circumstances can influence their overall intent to commit crime. It assumes that criminal acts are not random events, but are calculated by an offender. They are part of the routine social activities that people undertake in their day-to-day lives. Consequently, a criminal act is not perceived as something abnormal by an offender; rather it is seen as "an opportunity" which cannot be missed from being taken. If the suitably attractive target in the perception of the offender is unprotected by an adequate and capable guardian, and the rewards for committing the crime are sufficient to offset any potential penalties, the motivated offender will invariably commit that crime with respect to that particular target. Interestingly, this theory also postulates that a motivated offender is less likely to commit a crime if the rewards that they seek can be attained via legitimate means. This is a mainstay hypothesis that drives crime prevention and crime deterrent policies globally; and is the basis behind rational choice theory and its related subsidiary theory, crime pattern theory.

\subsubsection{Crime Pattern Theory}

With this theory from the point of view of both crime solving and crime prevention, it hypothesises that criminal behaviour is not a random event. It is a planned and/or an opportunistic event which is predictable, and with factors and determinants that can be exploited and curtailed by law enforcement agencies and practitioners. Factors and events such as when the routine "personal activity space" - and its "personal pathway" of daily activity - of a victim or a target "intersects" with a motivated offender's learned and routine modus operandi within the offender's very own personal "awareness space" (their "node"), and its "perimeter" of activity (Andresen \& Farrell, 2015; Brantingham, Brantingham, Song, \& Spicer, 2018). So knowing where motivated offenders reside and like to operate - together with the potential targets that are available to them within that locale and the modus operandi of the potential criminal acts that they can partake in - can be used to prevent and solve crime.

\subsubsection{Cultural Criminology}

$\mathrm{CC}$ is a comparatively new theory that opposes the more conventional, and more widely accepted, rational choice theories. The mainstay of this theory in attempting to explain offender behaviour is that criminal acts are driven largely by "personal emotions" which are motivated by a sense of "hopelessness" and a "lack of fear of authority" or punishment (Lilly et al, 2015). Crimes are not driven by rational or routine decision-making behaviours. Consequently, the ability to determine what motivates an offender to commit a crime is less predictable; making crime prevention more complicated. The proponents of cultural criminology conclude that modern crime is a result of the breakdown of culture and morality in the context of socioeconomic globalisation, and its concomitantly increasing socioeconomic inequalities within populations.

\subsection{Large Group Identity}

Within any society that has regressed in its social development and its traditional moral and ethical values, individuals will lose their innate personal identity. They become emotionally and psychologically vulnerable (Kernberg, 2020; Volkan, 2004). Subsequently, they adopt the identity, the character, and the persona of a larger group that exists within their general population. A larger group which they associate and identify with. This larger group is invariably headed by a leader who provides the whole group's individuals with the commensurate personal reassurances and its associated protection, and sometimes resources, from whatever existential threats that that group's individuals may perceive to exist to them personally. The leader purports to support the larger group's individuals in any activities (both the legal and the illicit) that they wish to partake in. Illicit activities that may include the deadly violent (Rabinovich \& Morton, 2011; Volkan, 2006). To distinguish whether such illicit behaviours are the acts of a free-thinking and independent individual or that of a group of regressed individuals - those that are ideologically motivated and have been sanctioned by the larger group and by its leader - can be difficult within a malignantly 
regressed society. Whether the crimes that are committed are considered to be the crimes of an individual or the collective crimes of the larger organised group - and therefore the offender will be apportioned impunity from accountability by the larger group and by its leader - requires an appreciation of the social status of that population's "Masse" psychology. In 1921, the psychoanalyst Sigmund Freud (1921) helped to first develop the concept of Masse; which refers to a group of individuals, or an organisation, that is collectively united by a common ideal and purpose. United by a common sense of identity that is usually related to race, religion, nationality, or another particularly sectarian ideology such as tribal ethnocentrism. All of this occurs under the direction of one particular and identifiable leader. Vamik Volkan (2004) has proposed a concept that builds on Freud's, and others', Masse group psychoanalysis works; with a concept that he has termed "large group regression" (Kernberg, 2020). Volkan's work has focused on the study of human behaviour within naturally occurring groups in times of political and religious crisis or conflict. He refers to Masse psychology in the same context as Freud's analysis of mass movements; they being united by a common sense of ideological cohesiveness, fraternity and values. A common ideology which indicates their collective disposition, and their relationship with a narcissistic leader. Volkan (2006) postulates that under group psychological and social trauma -particularly anxiety following a man-made or natural disaster - the collapse of traditional moral and cultural structures that regulate the daily lives of individuals, leads towards a broad social regression within the population. If this regression becomes manifested in violent and destructive behaviours, then the societal regression becomes malignant. An individual's inherently unique status and personal role in their society disappears; and they adopt the persona and behaviours of the larger group in a manner termed the "second skin". This second skin affords both the regressed individual and the regressed larger group with a modicum of an identity that is both collectively protective and nurturing. Any external threats to this second skin are seen as threats to the individual and to their larger group as a whole by association. This ultimately leads to conformity being demanded by the large regressed group's individuals; and especially by that regressed group's narcissistic leader. The leader is then able to call upon a joint and collective action to address any threats to the group, both internal and external threats, and they are able to also call upon the same collective response towards any threats - be they real or artificially fostered and perceived - that are aimed towards them as the leader of the group. The leader is able to garner prompt sentiment (Nationalism or Patriotism) from the larger group via both "chosen glories" (past chosen triumphant historical events of the population) and "chosen traumas" (past chosen traumatic historical events of the population). Sentiment which he/she is also able to use at his/her own behest for whatever ends that he/she deems fit for himself/herself. This may include the embellishing and modifying of the population's true past historical events in a manner that reinforces his/her control over it. This creates a "time collapse" for the regressed group. This being an inability for the group to then be able to move forward and away from its social regression. Political, ethnic and religious ideologies invariably contain such emotive foundations to their modus operandi within regressed large groups. However, within organised crime groups and their beneficiaries' networks, these irrational humanistic ideologies are commonly absent. Their presence would pose a significant operational threat to the group's consistent and perpetually profit-making activities. However, they may be artificially fostered and contrived in order to act as a distraction attention away from the organised group's illicit and criminal activities.

\section{Methodology}

Fifty-Four semi-structured interviews with senior-grade ranking (Lieutenant General, Major General, Brigadier General) and middle-grade ranking (Major, Brigadier, Captain) officials within the South Sudan National Police Service (SSNPS), the South Sudan National Security Service (NSS), the South Sudan National Army (South Sudan People's Defence Force - SSPDF), and senior public servants from the Government of South Sudan (GOSS - including from the Central Bank of South Sudan) were undertaken by the author over a 6 Year and Six Month period. Interviews were undertaken between 1 July, 2013 and 31 December, 2019, inclusive.

Fifteen open-ended questions were posed to every interviewee within either recorded face-to-face or recorded telephone/video call interviews. Interview times ranged from One hour to 8 hours in length; with a median of Three hours. Full anonymity was offered to each interviewee for reassurance prior to participation. All 54 interviewees opted for anonymity; and all were satisfied to have their responses, including their rank and titles, quoted within any subsequent reports. Information attained via corroboration of similar responses to independent questioning from at least three separate interviewees was deemed as reliable information suitable for study analysis. The following groups of South Sudanese individuals were interviewed over the total length of the study. Number of separate interviewees interviewed is indicated in brackets:

\section{The SSNPS (29); The NSS (14); The SSPDF (8); The GOSS (3)}

The Fifteen questions asked to each interviewee were as follows:

\section{1. "How significant is organised crime in South Sudan?"}

2. "What is considered to be organised crime?"

\section{3. "Who are the main people engaged in illicit activities under the definition of organised crimes?"}

4. "Which South Sudanese political groups, if any, participate in illicit and illegal activities, and when did they begin?"

\section{5. "From which countries do the non-political organised groups operating in the country come from?"}

6. "What kind of illicit and illegal economic activities do the organised groups participate in?"

\section{7. "How significant is political corruption in facilitating organised crime? Which political groups are involved, if any?"}

8. "Is there an official government policy for addressing organised crime? How effective is the government in solving and preventing organised crime? What stops the fight against organised crime from being effective, if it is not effective?" 


\section{9. "How easy, or difficult, is it to disrupt organised criminal networks; and why is it hard or easy to do?"}

10. "How many successful prosecutions for organised crime have been recorded since the country's independence in 2011?"

11. "How significant is violent crime in South Sudan?" Violent crime being defined as "murder", "rape", "kidnapping" or "armed robbery" (including "cattle rustling")

12. "Is organised crime associated with violence?"

\section{3. "Is religious and/or ethnic extremism a significant component of organised crime?"}

14. "Do you think that there is an association between violent crime and political corruption in South Sudan?"

\section{5. "Do you think that there is an association between religious and/or ethnic extremism and violent crime in South Sudan?"}

Alongside interviews, an online review of publicly available crime data for South Sudan was undertaken from the period of 1 January, 2005 until the 31 December, 2020, inclusive.

Network diagrams were constructed from the analysed interview data; with the SPLM-In-Government (SPLM-IG) and the "significant individual of interest" - the chairman of the SPLM-IG and the Head of State of the Republic of South Sudan, President Salva Kiir Mayardit - as their central points of reference. The network diagrams were created using Wondershare EdrawMax, version 10.1.5, by EdrawSoft.

\subsection{Null Hypothesis}

A null hypothesis - "Violent crime in South Sudan is not associated with ideological extremism"- was postulated and assessed under the assumptions that: "Political corruption is associated with organised crime", violent crime being a significant aspect of organised criminal behaviour, and; "Political corruption in South Sudan is not significantly driven by ideological extremism in the form of religion and/or ethnocentrism."

\section{Findings}

\subsection{SPLM SubGroups Network Diagram}

(see Supplementary Files for diagram)

As indicated with the "SPLM - Sub-Groups" network diagram, the formerly unified large SPLM group has fragmented over time since the year 2009. The central group is now called the "SPLM-In-Government" (SPLM-IG) and reflects the incumbent autonomous government of the previous southern Sudan, now the government of an independent sovereign State called "South Sudan" from 9 July, 2011. The formally recognised leader of the SPLM-IG group is the current President and the Head of State of South Sudan, "Salva Kiir Mayardit". Salva Kiir has been in this leadership position since August 2005 following the sudden death of the SPLM's previous leader, John Garang De Mabior. Garang died within a helicopter crash whilst he was returning back from Uganda. The helicopter belonged to the still current President of Uganda, Yoweri Kaguta Museveni, who is a close political and military ally of Kiir's SPLM-IG subgroup (See "Political SubGroups" network diagram below). The majority of the formerly unified SPLM group have remained loyal and subordinate to Salva Kiir since August 2005. The SPLM group has maintained its governance control over the sovereign territory of South Sudan to the date of this study; and this has continued with the Kiir-led SPLM-IG subgroup since December 2013, following a significant fragmentation of the unified SPLM group. Both "genuine" and "disingenuous" opposition SPLM subgroups have been established off of the formerly unified large SPLM group. These have been created by their respective leaders in order to both genuinely challenge the SPLM-IG's control of governance of the territory of a sovereign South Sudan, and to appear to be challenging the SPLM-IG'S control of governance. In the main instance, a Riek Machar Teny led subgroup named the "SPLM-In-Opposition" (SPLM-IO) has attempted to genuinely present itself as an alternative opposition subgroup that is of equivalent stature in terms of its economic and political influence to the larger Kiir-led SPLM-IG subgroup. This challenge has been ongoing since March 2014. As an additional response to this claim by the SPLM-IO subgroup, other subgroups subsequently emerged and they too fragmented off from the formerly unified large SPLM group. Machar has been the First Vice President of southern Sudan and then South Sudan - since August 2005 to date. There was a hiatus from April 2013 till April 2016; and then again from August 2016 till February 2020 when he was forcibly run out of the capital city and the seat of government of the country (Juba), with failed attempts to kill him by the Kiir-led SPLM-IG subgroup.

\subsection{Additional Subgroups in Genuine Opposition tothe SPLM-IG Subgroup}

The SPLM-Former Detainees/Political Leaders (SPLM-FD) subgroup emerged in 2014 under the leadership of the wife of the former leader of the large and unified SPLM group, Rebecca Nyandeng De Mabior. This previously genuine opposition subgroup has subsequently split into two separate subgroups; unofficially named the "SPLM-FD-Inside-Government" still under Nyandeng's leadership, and the "SPLM-FD-Outside-Government". The SPLM-FD-OutsideGovernment subgroup has remained a genuine opposition to the Kiir-led SPLM-IG subgroup. They are now named the Real-SPLM under the leadership of Pa'gan Amum Okiech and Oyay Deng Ajak, both of whom were former senior members of the unified SPLM group under John Garang's leadership, and then Salva Kiir. The Real-SPLM was formed in August 2019 and now exists within a coalition group called the South Sudan Opposition Movements Alliance (SSOMA) formed in August 2019.The SPLM-for Democratic Change (SPLM-DC) subgroup emerged in 2009. It was subsequently renamed the National Democratic Movement (NDM) in 2016. It became a member of the South Sudan Opposition Alliance (SSOA) coalition in 2017 under the same leader, Lam Akol Ajawin. A separate subgroup of the SPLM-DC splintered-off at the same time as the NDM was formed in 2016, and under the leadership of Ajawin's deputy, Onyoti Adigo. The SPLM-DC subgroup led by Adigo then became a disingenuous opposition subgroup to the Kiir-led SPLM-IG. The NDM subgroup of Ajawin 
remained in genuine opposition to the SPLM-IG. The NDM of Ajawin remains a member of the SSOA but its subgroup's opposition is now in contrast to the other members' of the SSOA coalition. The National Salvation Front (NAS) subgroup led by Thomas Cirillo Swaka was formed in 2017. It is within a coalition of subgroups called the South Sudan National Democratic Alliance (SSNDA) formed in 2018. The SSNDA coalition's subgroups were formerly within the SSOA coalition; a genuine opposition to the Kiir-led SPLM-IG which contained the NDM and the then unified SPLM-FD subgroup. The NAS subgroup and the SSNDA are now part of the SSOMA coalition of subgroups which is in genuine opposition to the SPLM-IG.

\subsection{Subgroups in Disingenuous Opposition to the SPLM-IG Subgroup}

The South Sudan Opposition Alliance (SSOA) is a coalition of pro-SPLM-IG subgroups formed in 2017 with several leaders (Josephine Lagu, Hussein Abdelbagi, Gabriel Changson Chang, Joseph Bakasoro, Denay Jock Chagor). Several of the coalition's founding subgroups, now collectively called the SSNDA, splintered-off in 2018 in order to remain in genuine opposition to the Kiir-led SPLM-IG subgroup. The South Sudan United Front (SSUF) subgroup emerged in 2018. It was formerly a member of the SSOMA coalition together with the R-SPLM and the SSNDA. In 2020, the subgroup splintered-off into two factions; one led by its leader, Paul Malong Awan, and the other faction (the SSUF-Progressive) led by its former spokesperson, Emmanuel Sunday de John. Both SSUF factions were expelled from the SSOMA coalition by the SSNDA coalition when Malong was accused of colluding with the SPLM-IG. The SSUF-Progressive faction led by Sunday de John was under consideration by the SSNDA coalition for readmission back into the SSOMA coalition at the time of writing this study. The Other Political Parties (OPP) is a coalition of pro-SPLM-IG subgroups formed in 2010 and consolidated over subsequent years. Some of the coalition's subgroups' leaders - Martin Elia Lomuro of the South Sudan Democratic Forum (SSDF) and David Yau Yau of the South Sudan Democratic Movement-Cobra Faction (SSDM-Cobra), both subgroups being allies of the Security Affairs Advisor of the Kiir-led SPLM-IG, Tut Kew Gatluak, who is allied to the National Congress Party (NCP) subgroup which has associations with the now ousted from government in Sudan, President Omar Hassan Al-Bashir have been senior officials within the government of South Sudan alongside the Kiir-led SPLM-IG subgroup since 2013. Another subgroup of the coalition led by the maternal cousin of Kiir, Peter Mayen Majongdit of the People's Liberal Party (PLP), allied itself with the SPLM-IG subgroup in 2018. Peter Mayen Majondit becoming a senior official in the SPLM-IG governance structures in 2020.

\subsection{Interviews}

The types of crimes reported by the 54 interviews are all found under the Southern Sudan Penal Code Act 2008. (GOSS, 2008)

They include: Crimes Against the Body (including murder); Crimes Against Public Order (including public violence); Crimes Against Property (including cattle rustling and extortion); Morality Crimes (including prostitution); Gender and Marriage Related Crimes (including rape); Crimes Against Country or Government (including supply of arms and weapons); Crimes by or Relating to Public Servants (including corruption and graft in public office); Drug Crimes (including dealing in recreational drugs) and; and Other Crimes (including money laundering and economic crimes).

A summary of the responses given by the Fifty-Four interviewees are indicated in Figures 1 - 15 .

\subsection{1 "How significant is organised crime in South Sudan?"}

Excerpt taken from interview with a Lieutenant General of the SSNPS in late October 2019:

"It is very significant and happens alot. We have "Niggers" (the colloquial name given to criminal gangs in South Sudan by the police). They are South Sudanese, but they are being taught alot of bad things by foreigners. These gangs never used to be here."

\subsection{2 "What is considered to be organised crime?"}

Excerpt taken from interview with a Brigadier General of the NSS in early February 2018:

"Anything that is done illegally by a team of people, we consider it to be organised crime. These are: Money laundering and illegal foreign exchange selling; Gold extraction and its smuggling outside of the country without approval; The illegal selling of crude oil; The selling of weapons within the country; Providing private security services without authorisation; Telecommunications companies that monitor people without authorisation; The black market selling of commodities; The grabbing of other people's land and property, and building on them without approval; The black market selling of petrol, diesel and gas; The smuggling illegally of logged timber and poached wildlife; Prostitution; Recreational drug smuggling and drug dealing."

3.4.3 "Who are the main people engaged in illegal and illicit activities under the definition of organised crimes?"

Excerpt taken from interview with a Major General of the SSPDF in mid May 2017:

“Most of them are South Sudanese; but they don't do it alone. There is always a foreigner working with them. These foreigners are usually from north Sudan or East Africa. The Lebanese are also many here. They are not good people."

3.4.4 "Which South Sudanese political groups, if any, participate in illicit and illegal activities, and when did they begin?"

Excerpt taken from interview with a then, now a former, cabinet minister in the GOSS in early September 2019:

"All of the political leaders are involved. None of them is clean. The SPLM is the main one. Riek (Machar) was doing it with Salva (Kiir) since 2005. And after the war started, Riek continued to do it smaller with his IO (SPLM-IO) from 2014 with timber. Salva's group (SPLM-IG) now controls all of the oil and gold. Almost all of it, except for Thomas (Cirillo) who has been getting some gold and timber from his NAS since 2017. Lam Akol (NDM, formerly SPLM-DC) is still getting something from Khartoum and Malakal. He's always been getting something small since 2009 and 2010 before independence. The FD's (SPLM-FD) 
are still getting things from their friends in the SPLM-IG since 2014, and they're still getting something even after those of Pa'gan (Amum Okiech) and Oyay (Deng Ajak) left them. The SSOA people have been getting something from Kiir since 2017. Martin Elia (Lomuro), (David) Yau Yau and Kiir's cousin Peter Mayen (Majongdit) have all been eating from Kiir since 2010. Tut Kew (Gatluak) now gets more money from Kiir than anyone else since 2018 because of the good things he did in Khartoum (Sudan) with (Omar) Bashir and the new peace agreement to make Riek weak and accept the agreement. (Paul) Malong took alot of money when he was the Chief of Staff (of the SSPDF). He still has millions of (US) Dollars. He's been using them from Kenya since he left the country in 2017."

3.4.5 "From which countries do the non-political organised groups operating in the country come from?"

Excerpt taken from interview with a Lieutenant General of the Military Intelligence division of the SSPDF in early January 2018:

"Most of them are South Sudanese, but they work with people from: Sudan; Lebanon; Eritrea; Ethiopia; Egypt; the UK; Europe; Canada; Somalia; Uganda; Kenya; DR Congo; China; India; South Africa; Nigeria; Equatorial Guinea and; Chad."

3.4.6 "What kind of illicit and illegal economic activities do the organised groups participate in?"

Excerpt taken from interview with a Major General of the SSNPS in mid July 2015:

"We generally label them as: Money laundering and economic crimes; Gold and other precious minerals smuggling; Off-selling of crude oil; Arms dealing and security sector crimes; Commodities and services profiteering; Black market goods' trading; Land and real-estate grabbing; Black market petrol and diesel trading; Timber smuggling; Wildlife smuggling; Human trafficking, slavery and prostitution; Drug dealing and smuggling."

3.4.7 "How significant is political corruption in facilitating organised crime? Which political groups are involved, if any?"

Excerpt taken from interview with a Major of the NSS in early March 2019:

"Very significant. It is in the middle of everything. Every group is involved. Salva's (Kiir) people and Riek's (Machar) are the main ones. But all of them (SPLMDC/NDM, SPLM-FD, R-SPLM, SSOA, NAS/SSNDA, SSUF, OPP) use corruption."

3.4.8 "Is there an official government policy for addressing organised crime? How effective is the govemment in solving and preventing organised crime? What stops the fight against organised crime from being effective, if it is not effective?"

Excerpt taken from interview with a Brigadier General of the SSNPS in mid April 2017:

"There is no policy and no special department. We just have to treat it like any other crime that happens in the country. We don't get any help from the government. The government actually interferes alot in our work."

3.4.9 "How easy, or difficult, is it to disrupt organised criminal networks; and why is it hard or easy to do?"

Excerpt taken from interview with a Captain of the NSS in late December 2019:

"It would not be hard to stop the criminals if the big people (political and military leaders) in the government did not protect them."

3.4.10 "How many successful prosecutions for organised crime have been recorded since the country's independence in 2011?"

Excerpt taken from interview with a Lieutenant General of the SSNPS in late October 2019:

"It must be less than Fifty."

Excerpt taken from interview with a Captain of the NSS in late December 2019:

"I really don't know how many."

3.4.11 "How significant is violent crime in South Sudan?" Violent crime being defined as "murder", "rape", "kidnapping" or "armed robbery" (including "cattle rustling").

Excerpt taken from interview with a Brigadier of the SSNPS in mid November 2016:

"It is very significant. And what makes it worse is that guns are everywhere."

3.4.12 "Is organised crime associated with violence?"

Excerpt taken from interview with a Lieutenant General of the SSNPS in Late December 2019:

"Yes it is. It usually happens when there is a disagreement. Anyone can get a gun here very easily if they want it. Every household probably has one."

3.4.13 "Is religious and/or ethnic extremism a significant component of organised crime?"

Excerpt taken from interview with a Major General of the NSS in mid September 2019:

Page $8 / 24$ 
"No, they are not involved. It is just all about making money and being in control of that business."

3.4.14 "Do you think that there is an association between violent crime and political corruption in South Sudan?"

Excerpt taken from interview with a Major of the SSNPS in early July 2019:

"Yes, there is an association. Because when violence has been used we are not always able to investigate. We are blocked."

3.4.15 "Do you think that there is an association between religious and/or ethnic extremism and violent crime in South Sudan?"

Excerpt taken from interview with a Lieutenant General of the SSNPS in Late December 2019:

"No, there is no association. It is just criminal behaviour that the offenders think that they will escape punishment fo because others are doing it and getting away with it."

\section{Conclusion}

\subsection{Political SubGroups Network Diagram}

(See Supplementary Files)

\subsection{Economic SubGroups Network Diagram}

(See Supplementary Files)

Economic and political dependency are significant determining factors as to whether a subgroup is in genuine opposition to the Kiir-led SPLM-IG subgroup or it is in disingenuous opposition. The SPLM-IG subgroup controls over $90 \%$ of the financial and economic resources available to any subgroup within the territory of South Sudan; and that is by virtue of its label as the "Government of South Sudan", and Salva Kiir as "The President" and the "Head of State" of the country (World Bank, 2020). Consequently, the political and economic networks of the SPLM-IG subgroup - and particularly of its leader, Salva Kiir Mayardit are extensive both domestically and internationally. The political and economic control is mandated and secured, both within the country domestically and also internationally, via this recognised "sovereign legitimacy" of the Kiir-led SPLM-IG subgroup. The wide-ranging nature of the economic subgroups that exist in association with the SPLM-IG subgroup reflects a broad cross-section of socioeconomic sectors that have become susceptible to the activities of organised crime groups and their international networks since August 2005.Money-laundering has been the most pervasive illicit activity undertaken in partnership with the unified SPLM group since 2005. This has subsequently continued with the fragmented SPLM subgroups, and particularly with the SPLM-IG because of its overall control of the country's sociopolitical governance institutions. At least two of the "Economic Sub-Groups" currently linked with the SPLM-IG subgroup ("Lebanon" and "Somalia") were disclosed by all Four groups of interviewees to be associated with individuals that have links to international terror organisations; "Hezbollah" and "Al-Shabaab", respectively. Murder, violence, intimidation and extortion, cattle-rustling and dealing in arms and weapons (termed "Security") were reported as being primarily associated with the Kiir-led SPLM-IG subgroup and its allies, and secondarily with the Machar-led SPLM-IO subgroup.

In South Sudan, crime data is meant to be compiled quarterly and then made available for transparent public consumption annually. This process was meant to provide a foundation for improving the work of law enforcement and the criminal justice system following the country's independence in 2011 . The only comprehensive crime data that has been made available to date since independence has been for the first quarter of the year 2013 (January to March, inclusive) (South Sudan Police Service, 2013). The majority of people in South Sudan are reported to access justice through traditional mechanisms at their local grassroots' levels. These are predicated largely on common-law "blood-money compensation" as a means of justice. Custodial sentencing as punishment is commonly absent, and this also applies for violent crimes including murder and rape. The still inadequate statutory-law frontline infrastructure has limited the access to more contemporary criminal justice mechanisms. This has been reported as partly responsible for the non-reporting of recordable crimes nationally; and this was corroborated by all 29 SSNPS interviewees. Independent crime analysis during the study period reports an overall anecdotal increase year-upon-year in all categories of crime in South Sudan. Organised crime is not specifically categorised. Crimes that are commonly associated with organised criminal activities are highlighted as having increased (ENACT, 2019). The majority of this study's interviewees (51) also corroborated this finding. The SSNPS, NSS and SSPDF interviewees attribute the anecdotal increase in crime rate to a variety of factors, including the socioeconomic growth of South Sudan's metropolitan areas since the country's independence. They state that this has resulted in an increase in the metropolitan populations, with the concomitantly greater opportunities for criminal activities to take place. Additionally, the SPLM-IG subgroup has deemed the increase in the number of reported crimes as positive and more of an indicator that the public are beginning to move away from traditional justice mechanisms and more towards contemporary statutory-law procedures. The SPLM-IG perceives this as a progressive step in its nation-building project and not an indication that crime rates are actually rising in real terms. The public dissemination of crime statistics for just one quarter of one year since the country's independence has been attributed to political instability and civil war. The SPLM-IG government states that the cessation of police training and support from the United Nations Development Programme since 2013 has impacted negatively on the official recording of crime statistics. All 54 interviewees did not agree with this assessment, and they attribute the lack of reporting to political corruption within the relevant institutions of South Sudan's government.

All 54 interviewees stated that the optimum conditions required by traditional organized criminal groups to operate successfully within any particular territory, are present within the new country of South Sudan. Whole sectors of the economy in South Sudan are reported as currently being "captured" by organised groups. Of the Twenty-Nine members of the SSNPS interviewed, 10 could state how many individuals had been convicted of crimes attributable to "organised crime". This figure being less than Fifty convictions within each disclosure. 


\subsection{Null Hypothesis}

The unified SPLM group's and the SPLM-IG subgroup's governance of South Sudan has been devoid of any consistent political, religious or other spiritual ideology. It has been driven by a desire for personal economic and material gain. Consequently, the null hypothesis can be accepted: "Violent crime in South Sudan is not associated with ideological extremism."

\section{Discussion}

The theory put forward by some scholars that organised crime is more a consequence of political failure than it is a failure of law enforcement practices - the latter being controlled and largely accountable to the former - is arguably cogent in the case of South Sudan (Allen, 1962; Tilly, 1985). As a senior foreign diplomat from a Western European country stated within a conversation with this author in 2011 after South Sudan's independence: "If contracts and the rule of law are not properly honoured in South Sudan, then no transparent and legal business - both foreign or homegrown - will operate in this new country for a long time". That was because of the pervasive and cancerous nature of the corruption that existed and its association with organised criminal activities which manifested themselves under different labels.

As largely accepted by most academics and practitioners, organised crime originated in Italy with "La Cosa Nostra" ("The Mafia") (Balsamo \& Carpozi, 1999). Many African countries have yet to formally identify the need to define organised crime never-mind combat the phenomenon (Lebeya, 2012). The identification of specific serious and predicate offences within the categorisation of organised crime urgently needs to be made for the purposes of statutory legislation in South Sudan. Some commentators have attributed the illicit activities in South Sudan to a "Politics of Fear", or a social stratification concept that is underpinned by an "entitlement ideology" that emanates from the post-South Sudanese liberation cohort of individuals colloquially termed "The Gun-Class" (D'Agoôt, 2018; Thiong, 2021). However, these sociology theories downplay the inherently criminal nature of the activities that are being undertaken. By downplaying this detail, these theories have affirmed the activities as "normal" and therefore "to be expected" within South Sudan. These and other similar narratives have only served to perpetuate and consolidate the illicit activities of organised criminal groups and their networks (Laudati, 2011). Whether intentionally or not, these theories have served to obfuscate and misinform both domestic and international stakeholders away from focusing on the clearly serious and dangerous illicit activities that are being partaken in within South Sudan. Activities which in most other countries in the world would unequivocally be prosecutable under punitive statutory laws. Additionally, there has been this narrative from both South Sudanese and non-South Sudanese commentators that the failure of the newest country in the world was somewhat inevitable. However, the scholarship thus far as to why the failure was inevitable has not been entirely convincing. What this author argues is that the root cause of any failure in South Sudan is far more straightforward to explain empirically within the confines of environmental criminology, alongside South Sudan's ubiquitously narcissistic and malignant leadership style over a socially regressed population following decades of civil war. This author postulates that South Sudan is being governed by an organised crime group which has both domestic and foreign enablers intentionally and calculatingly engaged through rational choice in routine and illicit economic activities at all levels of the new country's fledgling sovereign governance institutions. A perpetual pattern of illicit activity that ranges from the smuggling of natural resources and extortion, to money laundering. Akin to a caliphate of the so-called "Islamic State" in Libya or Syria, the current governance of South Sudan is no different except for its lack of a religious and humanistically emotive ideology underpinning its principles. This arguably excludes the "irrational choice" theory of cultural criminology in the context of South Sudan; and supports the rational choice environmental criminology theories that pertain to the modus operandi of motivated offenders.

It has been commonly conveyed that the sociopolitical governance ideology of South Sudan is ethnocentrism or tribalism; and that this is what has resulted in a failure of leadership and a political deadlock in the new country. However, this notion can be challenged by the fact that the largest fragmented SPLM subgroup - the SPLM-IG - is composed of individuals and allied-sub-groups that come from the most diverse range of ethnic groups and tribes in the country. Additionally, the very same Kiir-led SPLM-IG subgroup was reported by all of this study's interviewees - and it has been noted empirically by other independent stakeholders - as violently targeting and extrajudicially killing individuals which hail from the very same ethnic group as its powerful leader, Salva Kiir Mayardit. Killings which have taken place under SPLM-IG facilitated impunity, with SPLM-IG obstruction of attempts by law enforcement agents to apprehend and prosecute identified perpetrators. Consequently, the ideology of the multi-ethnic cohort that comprises the SPLM-IG may be more appropriately described as "personal profit-making". A Mafia-like organised crime group whose primary purpose is to repeatedly extract huge profits from its activities under the umbrella and veneer of a legitimate sovereign government of a Nation-State. As with other continental African politico-military entities empowered-by-default with governance responsibilities, the SPLM automatically became "the guardian" of the territory called southern Sudan in 2005. Unfortunately, and instead of developing into a law-abiding and transparently legitimate administrator, the post-liberation SPLM group transformed into an organised criminal group (a motivated offender) rationally engaging in illicit activities. The once "capable guardian" became absent when the opportunity to take the target (the territory of South Sudan with its significantly lucrative socioeconomic resources) arose. Whether that large unified SPLM group would have still become illicit under its former leader, John Garang De Mabior, continues to be debated by the vast majority of South Sudanese people. However, and what has become increasingly clear from the current state of failure in Nation-State formation and fragility, this has occurred under Salva Kiir since Garang's death. Some evidence that further supports the argument that Salva Kiir is "a significant individual of interest" is provided threefold:

1. Following the first Sudan civil war; between 1972 and 1978 the then southern Sudan was autonomously governed by the people of south Sudan themselves under the leadership of Abel Alier within a multi-ethnic, semi-autonomous civil administration. Abel Alier, likewise with John Garang, hailed from the same "Dinka" (Jieng) ethnic group as Salva Kiir. Insecurity and violent crime were reported as rare under the Alier-led southern Sudan government. When it did occur, the law enforcement agencies and the criminal justice system were functional. The general population within the territory of southern Sudan had faith in their efficiency to maintain law and order and deliver justice. Corruption was also reported as being relatively non-existent, with government officials that partook in graft and abuses of power in public office being dismissed and held accountable accordingly (Alier, 1999; Johnson, 2011).

2. Under the previous Garang leadership of the unified SPLM group, a general sense of goodwill and faith in criminal justice and the enforcement of the rule of law existed amongst the majority of the population of southern Sudan during the 1983 to 2005 second civil war. This faith and goodwill existed within the 
SPLM occupied and administered areas, and with the larger international community. This goodwill was important in facilitating support for southern Sudan's independence claims (Hamilton, 2011; Sawyer, 2002).

3. Even after the unified SPLM has fragmented into several different subgroups over recent years, the Kiir-led SPLM-IG has remained in overall control of the governance of South Sudan. Both domestic and transnational organised criminal activities thrive within the country. The one significant constant since August 2005 is Kiir's leadership and its overarching control of the institutional structures and decision-making processes of South Sudan's governance. This has been made intentionally possible via a transitional constitution that has been in existence since 2005. A transitional constitution that has had no significant amendments made since the country's independence in 2011. The current transitional constitution grants the President exceptional executive powers that have few independent checks and balances for oversight. All major government decision-making is routinely undertaken by unilateral Presidential decrees which are read out on State television (Constitute, 2017; GOSS, 2011; Henneberg, 2016).

The presence of organised crime appears to depend on Salva Kiir remaining as "the Boss" of the territory of South Sudan. Consequently, Kiir would be a valuable and "significant individual of interest" to consider targeting if organised crime in South Sudan is to begin to be definitively addressed and disrupted. A disruption that could tangibly open up a path towards illicit socioeconomic activities and violent crimes becoming punishable with equitable consistency. What is notable however, is that the criticism for the current State failure in South Sudan is rarely apportioned towards Salva Kiir separately. The criticism tends to be generalised to include all of South Sudan's political actors, including the other smaller SPLM subgroups' leaderships. The Fifty-Four South Sudanese interviewees within this study disclosed that this collective responsibility label has facilitated Kiir to be able to regularly evade individual culpability and personal accountability. It has afforded him with "an alibi". It has been an important contributing factor towards permitting the consistent activities of organised criminal groups and their networks to remain perpetual within South Sudan. As observed in other countries, both domestic and transnational organised criminal groupsdepend significantly on astable and persistent Boss remaining as the overall arbiter of the rule of law of the territory that the groups operate within (Stanislav, 2017).

After 9 years of independence, South Sudan still has not held any general elections for its population to be able to democratically elect new political leaders for their government. Elections were meant to have been held in 2015. A reason that has been consistently given by the Kiir-led SPLM-IG and its beneficiaries' network, is that the country has been at war and is unable to hold elections whilst millions of its population are currently displaced as refugees. However, this argument can be challenged by the fact that southern Sudan's government was previously able to practically organise and arrange to hold its independence referendum in January 2011 despite the absence of a significant number of its voting electorate and population from the country at that time. The then absent population and electorate were able to vote in abstentia wherever they where, be that inside the country or abroad in country's as far as Australia. There still appears to be no appetite from the SPLM-IG-controlled administration to hold elections any time soon in case one or more of its integral subgroup's members might lose out at the ballot box.

Almost all of the responsibilities of any functional government are currently undertaken in South Sudan by one of the largest United Nations' Missions in the world (United Nations Mission In South Sudan - UNMISS) and by foreign donor-funded international non-governmental organisations and humanitarian agencies. This has permitted the various SPLM subgroups to be able to focus primarily on their organised graft and rent-seeking activities without the consequences and burden of responsibility towards providing public services to the citizens of the new country (UN, 2019; USAID, 2020). The narrative that the SPLM government has routinely employed when criticised of this dependency is that these organisations are "South Sudan's development partners". "We are a baby Nation that has just been born - and like a human baby, we are fragile but have the potential to become great" (BBC News, 2011). In the same voice, known unscrupulous commercial activities are being undertaken by the various SPLM subgroups with other foreign individuals and entities. When questioned about these partnerships, the individuals and entities are labelled as "foreign investors" by the SPLM subgroups; and even when some of the individuals and entities are alleged to have been previously engaged in illicit and criminal activities in other countries (BBC News, 2020; Costanza, 2012; Daily Sun, 2017; Eye Radio, 2020; Ottolenghi, 2018; Strachan, 2019; The Sentry, 2019;The Sentry, 2019.b; The Sentry, 2021; UK Gov, 2021; USDT, 2019).

All of the SPLM subgroups foment insecurity and terror as a modus operandi within the sovereign territory of South Sudan. The SPLM-IG together with the SPLM-IO being the principle practitioners. As historically reported in Sicily, southern Italy, with reprisal killings, South Sudan has similar inter-communal grievances that are intentionally stoked-up by its organised criminal groups and their networks in order to gain and retain control of lucrative sociopolitical and socioeconomic territory (Al Jazeera, 2020; Cottino, 1990; Krause, 2019; Sparling, 2017). Cattle rustling, kidnapping, rape and murder are regularly employed and encouraged. Subjectively labelled as anthropological, and historical and cultural ethnic grievances and practices, these violent acts have been fomented by local SPLM subgroups' members in order to promote their importance to a subgroup's enterprise. With a socially regressed population, an inadequate criminal justice system, and a significant prevalence of firearms and weapons in the hands of civilians, the population resorts to a reliance on vigilantism. Vigilantism and its associated instability which is encouraged by the SPLM-IG subgroup and the SPLM-IO. Interestingly, these types of violent incidents and crimes are reported as not having occurred during the unified SPLM group's leadership under its former leader, John Garang, without there being repercussions and punishment for perpetrators; nor under the southern Sudan governance of Abel Alier in the 1970s. The SSNPS, the NSS, the SSPDF and the GOSS interviewees agree that this has been intentionally fomented to create divisions within local populations and communities. Divisions which have then been exploited to demand allegiances from a specific sub-population under the slogan of "the SPLM government will help us". This is a similar strategy that was commonly employed by the International Criminal Court (ICC) indicted former President of the Sudan, Omar Hassan Al-Bashir, for three decades throughout the Sudan (ICC, 2009). A modus operandi for maintaining control over territory, and which ensured that any political dissent became fragmented and uncoordinated, and could ultimately be quelled.

Murder represents the most serious crime that any individual can commit. Consequently, it would be unusual to have an organised criminal group where one of its primary enterprises is killing. That would draw unnecessary attention towards the money-making business of the group. Additionally, the element of regular financial and/or other material benefit that results in the amassing of huge profits is invariably lacking with murder and other violent crimes. For an organised criminal group to engage in deadly violence as one of its main activities does not fit into the standard definition of organised crime. As disclosed by

Page $11 / 24$ 
all Fifty-Four South Sudanese interviewees, they stated that the organised crime groups in South Sudan do not engage in deadly violence as a principal enterprise. This assertion aligning with the standard modus operandi of organised crime groups in other countries. However, the use of fear and violence including murder - is a significant aspect of their modus operandi within the larger profit-making enterprise's scope (Tibbetts, 2003). Organised crime groups occasionally out-source to third-parties the violent acts that need to be performed. Out-sourcing does not take place in South Sudan. However, cooperation does take place with third parties when the violent act is to be undertaken abroad within another sovereign territory (UN Panel, 2019). Elements within and also out-with of South Sudan's regular armed forces and security apparatuses - gangs and assassins which are colloquially termed "Niggers", "Unknown Gunmen", or "Toronto boys" - are regularly recruited to undertake any violent act with the commensurate impunity from accountability made available afterwards.

Since organised crime is predicated solely on the amassing of wealth without drawing too much undue attention, corruption is a lower cost and lower risk modus operandi for lubricating the wheels of the enterprise rather than the use of violence. One of the main reasons why political corruption is so significant and important to address in South Sudan. With South Sudan considered as the most corrupt country in the world at the time of writing, political corruption and graft in South Sudan have been weaponised and used as a tool to maintain sociopolitical and socioeconomic control (Transparency Int'l, 2021). Consequently, it has permitted both domestic and foreign groups and their illicit networks to enter the country's territorial integrity with its liberal free market economic policies that were adopted in 2005. Had the previous leader of the unified SPLM group, John Garang De Mabior, still been in charge to this day, the governance policies on curtailing illicit activities and political corruption may have been different. Whether those policies would have worked to curtail the currently corrupted sociopolitical environment, can only be a topic of conjecture; but candidly and honestly stating what those measures may have been by those SPLM subgroups' members who would have been part of their promulgation and implementation, may still prove useful.

\subsection{Disrupting Organised Crime in South Sudan}

In referring in this study to a ruling sociopolitical entity that is a legitimate government of a sovereign Nation-State and territory, to disrupt any associated organised criminal group one must identify a significant individual -or individuals - of interest. This knowledge can then be employed in the subsequent attempts to curtail the larger network's illicit activities and operations. This study's focus on the SPLM in South Sudan can be replicated in other countries which are undergoing similarly difficult sociopolitical transitions towards a lawful Nation-State that respects the values of human rights and the rule of law. But for this to ultimately have a practicable purpose to effect accountability and change, the inherent sovereign immunity that is given to captured States and their organised illicit groups, needs to be re-addressed by the larger (and independent) international community and its multi-lateral organisations. Overcoming its Westphalian sovereignty agreements - in light of the fact that organised criminal groups and their networks, including international terror organisations, are now transnational in nature and do not respect international diplomatic protocols - is critically important for global peace and security (Patton, 2019; Zifcak, 2015). International terror organisations have been reported as using the sovereign territory of failed, or failing, country's just like South Sudan as amenable locales and havens for their terror financing activities. Since the South Sudanese component of this organised criminal network is largely devoid of any political, religious, or other spiritual ideology - it solely being driven by a desire for personal material and financial gain by its enablers - South Sudan is a perfect base for foreign criminal elements to source and finance their illicit transnational activities.

The desired characteristics of functional leadership of any organisation - including organised crime groups - requires several essential qualities that include: Intelligence; The ability to self-reflect; Some morality in daily decision-making with regard to the particular ethics of that organisation, and; Some small element of paranoid narcissism that fosters confidence in the leader's own abilities and desire to ensure successful operations of the organisation (Kernberg, 1998). Narcissistic and paranoid features are an important aspect of a leader of any functional group. However, when exaggerated and seemingly pathological these traits can become significantly disruptive and dysfunctional to any organisation's (or group of people's) growth and progress. Particularly one that is vulnerable for one reason or another. Within large group societal regression, the potential for a malignantly narcissistic and paranoid leader to emerge to lead the group becomes a compounding concern. This is precisely what occurred in South Sudan with its formerly unified SPLM group; and now with its various SPLM subgroups. In South Sudan as a consequence of decades of war, the emergence of individuals with these pathologically-exaggerated leadership characteristics has become important in providing a "second skin" to vulnerable sociopolitical and socioeconomic groups. Malignant narcissism is widely observable within the personality traits of the various leaders of the various SPLM subgroups. Such individuals adapt their personalities to social situations where large group regression calls for quick and prompt gratification of the regressed society. The various leaders of the SPLM subgroups in South Sudan - with the SPLM-IG and SPLM-IO being the two subgroups that manifest this most vividly with their leaderships - have exploited this vulnerable psychological Masse state. The leader's character becomes an essential aspect of the large organised group's modus operandi. Consequently, there is a high level of paranoia within the regressed group. With a frequent turnover and breakdown of middle to lower level membership, as has occurred with the SPLM and its subsequent and various subgroups. "Out-group" individuals have become labelled as "dissenters" of the "in-group", and they have become targets via way of disinformation which results in socioeconomic exclusion and even violent acts such as extrajudicial killings with impunity being meted out, regardless of the dissenter's ethnic background (Kernberg, 2003).

Since its independence in July 2011, South Sudan has only ever once officially reported its crime data publicly. This is considered to be reflective of the endemic political corruption within the country, and the lack of development of the law enforcement agencies and the criminal justice system. Non-Statesupported criminals ordinarily take great efforts to hide their illicit relationship networks as part of their modus operandi. This is to ensure that they are able to operate without detection and monitoring (NCIS, 2000). In South Sudan, State-supported offenders and their illicit organised groups find this easy with complicity from the same governance and security sector that is meant to obviate their criminal activities. The conducive and corrupted environment that has been created under the veneer of sovereign immunity has afforded State-supported criminal groups and their networks with a safe haven to be able to freely undertake their illicit activities without fear of punitive accountability (Uzzi \& Spiro, 2005). Similarly as with non-State-supported motivated offenders, to be able to identify the potential size of any illicit and criminal State-supported network in South Sudan - at both its domestic and transnational levels - one must understand the themes that link the individuals within the network and its subgroups together with a significant individual of interest (Liu, Patacchini, Zenou, \&

Page $12 / 24$ 
Lee, 2012). In this study, the leader of the SPLM-IG was reported as significant by all of the interviewees. Once a "first-level motivated offender" has been identified, extrapolating their larger illicit network towards possible other individuals and crimes that are linked becomes possible. The type of crime that has allegedly been committed by the significant State-supported individual, the level of intelligence information and data that is associated with other individuals within that crime type, together with any other information that has been attained via other serendipitous mechanisms, will all be invaluable for data-mining analysis of that State-supported motivated offender's criminal behaviour (Barabasi,2003; Xu \& Chen, 2005). South Sudan lacks data mining personnel within its law enforcement agencies. Whether this deficit of expertise is by choice (due to political corruption) or by accident (due to a lack of understanding and appreciation of its importance) is unclear. This author believes it to be due to the former by virtue of South Sudan's State-capture by organised crime groups.

The country's recently completed "National Dialogue" process appears to have further dispelled some of the long-standing theories of ethnocentric ideology in themal-governance of South Sudan. It has called for the exits of both Salva Kiir and Riek Machar from the country's sociopolitical leadership and governance structures. Each individual hailing from two different majority ethnic groups (Eye Radio, 2020.b). To no surprise to the millions of South Sudanese and foreign stakeholders who still take an interest in the fate of the new country and its citizens, both subgroups' leaders and their respective SPLM subgroups have thus far at the time of writing of this study, refused to accept this recommendation. Many South Sudanese citizens also hold key foreign stakeholders which supported South Sudan's independence - particularly the past governments of the United States of America, the United Kingdom, and Norway, collectively termed "the Troika" - culpable in South Sudan's failure of State formation alongside the SPLM subgroups (Riak, 2021; Young, 2021). Whether this assertion is correct or not remains inconclusive. Whether it has been by accident or by design because of official diplomatic policies, remains a topic of popular debate both within South Sudan and abroad. However, what is clear is that South Sudan's foreign stakeholders have been inconsistent in their actions towards furthering accountability and justice for South Sudan's mal-governance and organised criminal behaviours. Resultantly, this has aided and abetted the impunity in South Sudan. In particular, there has been a lack of personal accountability aimed towards Salva Kiir Mayardit (Shackleford, 2020). Kiir has been unequivocally supported by most of South Sudan's foreign stakeholders, including by the Troika, and even amidst independently credible accusations of war crimes and crimes against humanity being allegedly committed under his leadership (AU, 2014). War crimes and crimes against humanity which the African Union continental administrative and diplomatic bloc has mandated an independent tribunal - the "African Union Hybrid Court for South Sudan" - to hear evidence and try alleged perpetrators within (IGAD, 2018). However, the Kiir-led SPLM-IG subgroup has been obstructing for almost six years any transitional justice processes that would involve punitive accountability (AU, 2014; Gramer, 2019; Kiir \& Machar, 2016; UNCHRSS, 2021). Encouragingly, the majority of the citizens of South Sudan do not agree with this call by the SPLM-IG for non-punitive justice and accountability (Amnesty, 2019).

\subsection{Implications}

The 2013 post-independence SPLM/SPLA conflict and its ongoing skirmishes, has essentially been a turf war between the various fragmented SPLM subgroups. A territorial turf war over who will ultimately control the historical, liberation-time, "brand name" and legacy of the SPLM/SPLA with its inextricably linked politico-military benefits. A brand that brings with it ready-made psychosocial-capital advantages that can then be employed by the victorious SPLM subgroup to continue to exploit the territories of the majority of South Sudan's over ten million population. Territories that are endowed with lucrative natural resources and socioeconomic benefits. Territories that are still owned by a diverse ethnic and cultural indigenous population comprising of at least 64 different tribes who are widely distributed within a new country that is over two and a half times the size of the United Kingdom.

The gaslighting that is mobilised by the malignantly narcissistic leadership over a socially regressed and sequacious South Sudanese population, is undertaken to ensure that any leader of any subgroup is able to convey their alleged value to being (and remaining) part of a particular SPLM subgroup's enterprises. Thus far, and largely by virtue of Salva Kiir's status as the recognised Head of State, the SPLM-IG subgroup garners most foreign international support; including military support from neighbouring countries like Uganda. How long that this will last foris unclear by virtue of the country's continued failed status and fragility. What is becoming increasingly clear however as South Sudan moves towards its first ever national general elections, is that any process that abruptly removes Kiir from his "significant individual of interest" position jeopardises the ongoing and perpetual success of the business of the whole SPLM-IG subgroup. There appears to be no clear and ready-made unifying successor to take over the leadership mantle and become the "stable Boss" of the SPLM-IG. Consequently, some of the other leaders of the other fragmented SPLM subgroups, including those that have been in genuine opposition to the SPLM-IG subgroup, have begun to engage in reconciliation talks over recent months with both Salva Kiir and his representatives from his SPLM-IG subgroup. The objective of these negotiations are to try to facilitate the return of some of the key leaders of the fragmented SPLM subgroups back towards the larger SPLM-IG subgroup. Ultimately, to then once again become a wholly unified SPLM group (CCM, 2015). Whether these negotiations with the SPLM-IG subgroup shall succeed will be determined largely by whether the ideology of the other subgroups has remained as personal economic interest or if it has become more sociopolitical and/or ethnically emotive. This author believes that the vast majority of the fragmented SPLM subgroups, including those that are still in genuine opposition to the Kiir-led SPLM-IG, remain with the same former ideology of the unified SPLM group - "personal economic gain". An ideology of oligarchy and kleptocracy that assists in the amassing of huge personal profits and wealth by individual members of an organised crime group that has amenably facilitating sovereign immunities as a principal component of its modus operandi.

This study's use of environmental criminology and large group population psychoanalysis to empirically explore State-sponsored organised crime, is novel within the current literature. In this case of a new African country, large group psychoanalysis and the theories of environmental criminology which have formulated a crime triangle - a motivated offender (a significant individual of interest), a victim (an unprotected population), and a location (a sovereign Nation-State that has little to no independently functioning judiciary or law enforcement agency due to political corruption) - can be reliably applied to investigate State-supported motivated offenders and their organised criminal groups and networks within South Sudan. These theories and concepts can be further applied to other sovereign kleptocracies and oligarchies globally. With a functional view to disrupting similar practices that: Challenge democracy; Undermine the international rules of law and human rights, and ultimately; Threaten global peace and security via dangerous transnational mechanisms made amenable by failed or failing Nation-States, such as the financing of foreign terrorist organisations.

\section{Declarations}


Competing Interest: Competing interests: The authors declare no competing interests.

\section{References}

Acemoglu, D., Robinson,J., Verdier, T.(2003). Kleptocracy and divide and rule: A model of personal rule. Journal of the European Economic Association, 2 (23),162-192.https://doi.org/10.1162/154247604323067916

Alier, A. (1999). Southern Sudan: Too Many Agreements Dishonoured. Reading: Ithaca Press.

Al Jazeera. (2020). Hundreds killed in inter-communal clashes in South Sudan. Doha: Al Jazeera News.

https://www.aljazeera.com/news/2020/5/20/hundreds-killed-in-inter-communal-clashes-in-south-sudan

Allen, E. J. (1962). Merchants of menace: The mafia: A study of organized crime. Springfield: Charles C Thomas Publishers.

Amnesty. (2019). South Sudan: Crippled justice system and blanket amnesties fuelling impunity for war crimes. London: Amnesty International. https://www.amnesty.org/en/latest/news/2019/10/south-sudan-crippled-justice-system-and-blanket-amnesties-fuelling-impunity-for-war-crimes/

Andresen, M. A., Farrell, G. (2015). The criminal act: The role and influence of routine activity theory. London: Palgrave Macmillan.

AU. (2014). Final report of the African Union commission of inquiry on South Sudan. Addis Ababa: African Union Commission.

Balsamo, W., Carpozi, G. (1999). Crime incorporated or under the clock: The inside story of the mafia's first hundred years. Far Hills: New Horizon Press.

Barabasi, A-L. (2003). Linked: How everything is connected to everything else and what it means for business, science, and everyday life. New York: Plume Books.

BBC News. (2011). South Sudan chosen as name for new country. London: British Broadcasting Cooperation. https://www.bbc.co.uk/news/world-africa12478957

BBC News. (2020). Shepherd Bushiri: Preacher flees South Africa ahead of fraud trial. London: British Broadcasting Cooperation. https://www.bbc.co.uk/news/world-africa-54949819

Bovenkerk, F., Siegel, D., Zaitch, D.. (2003). Organized crime and ethnic reputation manipulation. Crime, Law and Social Change,39,23-

38.https://doi.org/10.1023/A:1022499504945

Branch, A., Mampilly, Z. C. (2005). Winning the war, but losing the peace? The dilemma of SPLM/Acivil administration and the tasks ahead. The Journal of Modern African Studies, 43(1), 1-20.https://doi.org/10.1017/S0022278X04000588

Brantingham, P. L., Brantingham, P. J., Song, J., Spicer, V.(2018). Advances in visualization for theory testing in environmental criminology. In The Oxford Handbook of Environmental Criminology, New York: Oxford University Press.

Bruinsma, G. J. N., Johnson, S. D. (Eds) (2018). The Oxford handbook of environmental criminology. New York: Oxford University Press.

CCM. (2015) Agreement on the Reunification of the Sudan People's Liberation Movement (Arusha Agreement). Arusha, Tanazania: Chama Cha Mapinduzi.https://www.peaceagreements.org/wview/906/Agreement\%20on\%20the\%20Reunification\%20of\%20the\%20Sudan\%20People\%27s\%20Liberation\%

Checchi,F., Testa, A., Warsame, A., Le, Q., Burns, R. (2018).Estimates of crisis-attributable mortality in South Sudan, December 2013-April 2018.London: Dept of Infectious Disease Epidemiology, Faculty of Epidemiology and Population Health, London School of Hygiene and Tropical Medicine.

Constitute. (2017). South Sudan's Constitution of 2011 with Amendments through 2013. London: Constitute. https://www.fd.uc.pt/g7+/pdfs/South_Sudan.pdf Costanza, W. (2012). Hizballah and its mission in Latin America. Studies in Conflict \& Terrorism, 35(3), 193-

210.https://doi.org/10.1080/1057610X.2012.648155

Cottino, A. (1999). Sicilian cultures of violence: The interconnections between organized crime and local society. Crime, Law and Social Change,32 (2), 103113.https://doi.org/10.1023/A:1008389424861

Craze, J. (2020). The Politics of numbers: On security sector reform in South Sudan, 2005-2020.London: London School of Economics.

Cullen, F. T., Kulig, T. C. (2018).Evaluating Theories of Environmental Criminology: Strengths and Weaknesses. In The Oxford Handbook of Environmental Criminology. New York: Oxford University Press.

D’Agoôt, M. (2018). Taming the Dominant Gun Class in South Sudan. Washington DC: Africa Centre for Strategic Studies.

Daily Sun. (2017). "Prince" Bushiri wows South Sudan. South Africa: Daily Sun Newspaper. https://www.dailysun.co.za/News/International/prince-bushiriwows-south-sudan-20171108 
Deng, D. K., Lopez, B., Pritchard, M., Ng, L. C. (2015). Search for a New Beginning: Perceptions of Truth, Justice, Reconciliation and Healing in South Sudan. South Sudan: South Sudan Law Society.

De Waal, A. (2014). When kleptocracy becomes insolvent: Brute causes of the civil war in South Sudan. African Affairs,113(452), 347369.https://doi.org/10.1093/afraf/adu028

DFID. (2018).South Sudan Profile: July 2018. London: Department for International Development. https://assets.publishing.service.gov.uk/government/uploads/system/uploads/attachment_data/file/ 723770/South-Sudan-July-2018.pdf

Dietz, M. G. (1990). Thomas Hobbes and political theory. London: Lawrence, Kan, University Press of Kansas.

Eifert, B., Miguel, E., Posner, D. N. (2010) Political competition and ethnic identification in Africa. Journal of Political Science,54(2), 494510.https://doi.org/10.1111/j.1540-5907.2010.00443.x

ENACT. (2019). Organised crime index Africa - South Sudan. https://ocindex.net/country/south_sudan

Eye Radio. (2020). South Sudan's consul to Lebanon is reportedly a "fugitive". South Sudan: Eye Radio Press. https://eyeradio.org/south-sudans-consul-tolebanon-is-reportedly-a-fugitive/

Eye Radio.(2020.b). J1 rejects ND report that asks Kiir and Machar to leave politics. South Sudan: Eye Radio Press. https://eyeradio.org/j1-rejects-nd-reportthat-asks-kiir-and-machar-to-leave-politics/

FinCEN. (2017). FIN-2017-A004: Advisory to Financial Institutions on Political Corruption Risks in South Sudan (6 September 2017).Washington DC: Financial Crime Enforcements Network. https://www.fincen.gov/resources/advisories/fincen-advisory-fin-2017-a004

FinCEN. (2018). FIN-2018-A003: Advisory on Human Rights Abuses Enabled by Corrupt Senior Foreign Political Figures and their Financial Facilitators (12 June 2018). Washington DC: Financial Crime Enforcements Network. https://www.fincen.gov/sites/default/files/advisory/2018-06-

12/PEP\%20Facilitator\%20Advisory_FINAL\%20508.pdf

Fleischacker, S. (2018). Dismembering the Human Character: Adam Ferguson's Conception of Corruption. Social Philosophy and Policy, 35(2), 54-

72.http://dx.doi.org/10.1017/S0265052519000128

Freud, S. (1921). Group psychology and the analysis of the ego. The standard edition of the complete psychological works of Sigmund Freud, Volume XVIII (1920-1922): Beyond the pleasure principle, group psychology and other works. http://freudians.org/wp-

content/uploads/2014/09/Freud_Group_Psychology.pdf

FSI. (2020). Fragile States index annual report 2020. Washington DC: The Fund for Peace.

GOSS. (2008). Southern Sudan penal code act 2008. South Sudan: Government of Southern Sudan.

GOSS. (2011). The transitional constitution of the Republic of South Sudan, 2011. South Sudan: Government of Southern Sudan.

https://www.refworld.org/pdfid/5d3034b97.pdf

Gounev, P., Bezlov, T. (2013) Examining the links between organised crime and corruption. Center for the Study of Democracy, Directorate-General for Migration and Home Affairs (European Commission). Brussels: EU publications.

Gramer, R. (2019). Former U.S. diplomats lobby to stop South Sudan war crimes court. Washington DC: FP

Group.https://foreignpolicy.com/2019/04/29/former-us-diplomats-lobby-to-stop-south-sudan-war-crimes-court-salva-kiir-lobbying-contract-africa-peace-dealriek-machar/

Hamilton, R. (2011). U.S. played key role in Southern Sudan's long journey to independence. Washington DC: The Atlantic.

https://www.theatlantic.com/international/archive/2011/07/us-played-key-role-in-southern-sudans-long-journey-to-independence/241660/

Henneberg, I. (2016). Text comparison of the interim constitution of southern Sudan (2005) and the transitional constitution of the Republic of South Sudan (2011).Freiberg: University of Freiberg.

ICC. (2009). Al Bashir Case: The Prosecutor v. Omar Hassan Ahmad Al Bashir - ICC-02/05-01/09. The Hague: International Criminal Court. https://www.icccpi.int/darfur/albashir

IGAD. (2018).Signed Revitalized Agreement On The Resolution Of The Conflict In South Sudan. Chapter V: Transitional Justice, Accountability, Reconciliation and Healing. Djibouti: Intergovernmental Authority on Development.https://igad.int/programs/115-south-sudan-office/1950-signed-revitalized-agreement-onthe-resolution-of-the-conflict-in-south-sudan

Johnson, H. F. (2011). Waging peace in Sudan: The inside story of the negotiations that ended Africa's longest civil war. Brighton: Sussex Academic Press.

Johnson, H. F. (2016). South Sudan: The Untold Story from Independence to Civil War. London: IB Tauris.

Page $15 / 24$ 
Justin, P. H., De Vries, L. (2017). Governing unclear lines: Local boundaries as a (re)source of conflict in South Sudan. Journal of Borderlands Studies, 34(1), 31-46.https://doi.org/10.1080/08865655.2017.1294497

Kernberg, O. F. (1998). Ideology, conflict, and leadership in groups and organizations. New Haven: Yale Univ. Press.

Kernberg, O. F. (2003). Sanctioned social violence: A psychoanalytic view: Part 2.Int. J. Psychoanal,84, 953-968.https://doi.org/10.1516/NNQX-V7X9-DGCVM8T8

Kernberg, O. F. (2020). Malignant narcissism and large group regression. The Psychoanalytic Quarterly,89(1), 1-

24.https://doi.org/10.1080/00332828.2020.1685342

Kiir, S., Machar, R. (2016). South Sudan needs truth, not trials. New York: The New York Times (Op-Ed

Contributors)https://www.nytimes.com/2016/06/08/opinion/south-sudan-needs-truth-not-trials.html

Kostakos, P. (2018). Public perceptions on organised crime, mafia, and terrorism: A big data analysis based on Twitter and Google trends. International Journal of Cyber Criminology,12(1), 282-299.http://dx.doi.org/10.5281/zenodo.1467919

Krause, J. (2019). Stabilization and local conflicts: Communal and civil war in South Sudan. Ethnopolitics,18(5), 478-

493.https://doi.org/10.1080/17449057.2019.1640505

Laudati, A. (2011). Victims of discourse: Mobilizing narratives of fear and insecurity in post conflict South Sudan - the case of Jonglei State .African Geographical Review, 30(1), 15-32.https://doi.org/10.1080/19376812.2011.10539133

Lebeya, S. G. (2012). Defining organised crime: A comparative analysis. Pretoria: University of South Africa (UNISA).

Lilly, J., Cullen, F., Ball, R. (2015). Criminological theory: Context and consequences (6th ed). Thousand Oaks: SAGE Publications.

Liu, X., Patacchini, E., Zenou, Y., Lee, L-F. (2012). Criminal networks: Who is the key player? FEEM Working Paper

No.39.http://dx.doi.org/10.2139/ssrn.2089267

Madut, K. (2020). Ethnic mobilization, armaments, and South Sudan's quest for sustainable peace. Peace Review, 32(2), 235-

243.https://doi.org/10.1080/10402659.2020.1836448

Mailey, J. R. (2015). The Anatomy of the resource curse: Predatory investment in Africa's extractive industries. ACSS Special Report No. 3 (May 2015); Washington DC: Africa Center for Strategic Studies.http://www.jstor.org/stable/resrep19167.1

Mallory S. L (2012). Understanding organized crime (2nd ed). Sudbury: Jones and Bartlett Publishers.

Marion, N. E. (2008). Government versus organized crime. New Jersey: Pearson Prentice Hall.

Navot, D. (2016). Real Politics and the Concept of Political Corruption. Political Studies Review, 14 (4), 544-554.https://doi.org/10.1111\%2F1478-9302.12079

NECC. (2020). South Sudan: Illicit finance risks. Reference: 0598-NECC. London: National Economic Crime Centre. https://nationalcrimeagency.gov.uk/who-weare/publications/428-amber-alert-south-sudan/file

Ottolenghi, E. (2018). State Sponsors of Terrorism: An Examination of Iran's Global Terrorism Network. Congressional Testimony: Foundation for Defense of Democracies. Washington DC: House Homeland Security Committee. https://docs.house.gov/meetings/HM/HM05/20180417/108155/HHRG-115-HM05Wstate-OttolenghiE-20180417.pdf

Patton, S. (2019). The peace of Westphalia and it affects on international relations, diplomacy and foreign policy. The Histories, 10(1), Article 5.https://digitalcommons.lasalle.edu/the_histories/vol10/iss1/5

Rabinovich, A., Morton, T. A. (2011). Subgroup identities as a key to cooperation within large social groups. British Journal of Social Psychology,50, 3651.https://doi.org/10.1348/014466610x486356

Riak, J. D. C. (2021). The birth of States: Successful and failed secessions. South Sudan: Africa World Books Pty.

Rolandsen, O. H. (2015). Another civil war in South Sudan: The failure of guerrilla government? Journal of Eastern African Studies, 9(1), 163-

174.https://doi.org/10.1080/17531055.2014.993210

Sahgal G., Zeuthen M. (2020). The nexus between crime and violent extremism in Kenya. The RUSI Journal (Aug 2020); London: Taylor \& Francis Group.

Sawyer, J. (2002). Sudan: John Garang Seeks Self-Determination. Washington DC: Pulitzer Center on Crisis Reporting.

https://pulitzercenter.org/reporting/sudan-john-garang-seeks-self-determination

Schomerus, M., Rigterink, A. S. (2016). Non-State Security Providers and Political Formation in South Sudan: The Case of Western Equatoria's Arrow Boys. Waterloo, Canada: Center for Security Governance. 
Shackleford, E. (2020). The dissent channel: American diplomacy in a dishonest age. New York: Public Affairs.

Siegel, D., Nelen, H. (2008) Organized Crime: Culture, Markets and Policies. New York: Springer.

South Sudan Police Service. (2013).Quarterly Crime Statistics: January - March 2013. South Sudan: Ministry of Interior, Government of South Sudan.

Sparling, R. (2017). The concept of corruption in J.G.A. Pocock's the Machiavellian moment. History of European Ideas, 43(2), 156-

170.https://doi.org/10.1080/01916599.2016.1198074

Stanislav, M. (2017). Oligarchs and corruption in Putin's Russia: Of sand castles and geopolitical volunteering. Georgetown Journal of International Affairs,18(2), 26-32.http://dx.doi.org/10.1353/gia.2017.0017

Strachan, A. L. (2019). Extremism, violent extremism and terrorism (EVET) in South Sudan. London: Department for International Development (DFID). https://assets.publishing.service.gov.uk/media/5cf66afe40f0b60a148f5727/533_EVET_in_South_Sudan.pdf

Tambulasi, R. I.C. (2009). The public sector corruption and organised crime nexus: The case of the fertiliser subsidy programme in Malawi. African Security Studies,18(4), 19-31.https://doi.org/10.1080/10246029.2009.9627555

The Sentry. (2016). War crimes shouldn't pay: Stopping the looting and destruction in South Sudan. Washington DC: The Enough Project.

The Sentry. (2019). The taking of South Sudan: The tycoons, brokers, and multinational corporations complicit in hijacking the world's newest state. Washington DC: The Enough Project.

The Sentry. (2019.b). Al Cardinal: South Sudan's original oligarch. Washington DC: The Enough Project.

The Sentry. (2020). Taking of South Sudan series - Making a killing: South Sudanese military leaders' wealth, explained. Washington DC: The Enough Project.

The Sentry, (2021). The metamorphosis of Ali Khalil Merhi: How a one-time fugitive found fortune in South Sudan. Washington DC: The Enough Project.

Thiong, D. A. (2021). The politics of fear in South Sudan: Generating chaos, creating conflict .London: Zed Books.

Tibbetts, S. G. (2003). Self-conscious emotions and criminal offending. Psychological Reports, 93(1),101-126.https://doi.org/10.2466\%2Fpr0.2003.93.1.101

Tilly, C. (1985). State formation as organized crime. In Evans, Peter, Dietrich Rueschemeyer,and Theda Skocpol (Eds), Bringing the State Back In. Cambridge: Cambridge University Press.

Transparency Int'I. (2021). Corruption perceptions index 2020. Berlin: Transparency International.

Tutlam, N. T., Flick, L. H., Xian, H., Matsuo, H., Glowinski, A., Tutdeal, N. (2020). Trauma-associated psychiatric disorders among South Sudanese Dinka and Nuer women resettled in the USA. Global Social Welfare,7,189-199https://doi.org/10.1007/s40609-020-00171-7

UK Gov. (2021). UK Sanctions 22 Individuals Involved in Serious International Corruption. London: Foreign, Commonwealth \& Development

Office.https://www.gov.uk/government/news/uk-sanctions-22-individuals-involved-in-serious-international-corruption

UN. (2019). Budget performance for the period from 1 July 2017 to30 June 2018and proposed budget for the period from 1 July 2019 to 30 June2020 of the United Nations Mission in South Sudan. New York: United Nations. https://undocs.org/pdf?symbol=en/A/73/755/Add.13

UNCHRSS. (2021). Report of the commission on human rights in South Sudan, A/HRC/46/53.Human Rights Council - Forty-sixth session. Geneva: United Nations. https://digitallibrary.un.org/record/3903406? In=en\#record-files-collapse-header

UNESCO. (2020). South Sudan commemorates international literacy day (ILD). Paris: United Nations Educational, Scientific and Cultural Organization. https://en.unesco.org/news/south-sudan-commemorates-international-literacy-day-ild

UNODC. (2004). United Nations convention against transnational organized crime and the protocols thereto: General assembly resolution 55/25. Vienna: United Nations Office on Drugs and Crime.

UN Panel. (2019). Final report of the panel of experts on South Sudan submitted pursuant to United Nations Security Council resolution 2428 (2018) S/2019/301 - Apr 2019. New York: United Nations.

USAID. (2020). South Sudan - Crisis. Washington DC: United States Agency for International Development.

https://www.usaid.gov/sites/default/files/documents/1866/07.24.20_South_Sudan_Crisis_Fact_Sheet_9.pdf

USDT. (2019). Treasury sanctions businessmen in South Sudan for corrupt dealings with government officials and sanctions evasion. Washington DC: US Department of the Treasury. https://home.treasury.gov/news/press-releases/sm790

Uzzi, B., Spiro, J. (2005). Collaboration and creativity: The small world problem. American Journal of Sociology,111, 447-

504.http://dx.doi.org/10.1086/432782

Page $17 / 24$ 
Van Dijk, J. (2007). Mafia markers: Assessing organized crime and its impact upon societies. In Trends Organ Crime,10, 39-56. New York: Springer.https://doi.org/10.1007/s12117-007-9013-x

Van Duyne, P. C. (1996). Organized crime, corruption and power. Crime Law Soc Change,26(3), 201-238.

Varese, F. (2001). The Russian mafia: Private protection in a new market economy. Oxford: Oxford University Press.

Volkan, V. D.(2004). Blind trust: Large groups and their leaders in times of crisis and terror. Charlottesville, Virginia: Pitchstone Publishing.

Volkan, V. D. (2006). Killing in the name of identity : A study of bloody conflicts. Charlottesville, Virginia: Pitchstone Publishing.

Warren, M. E. (2004). What does corruption mean in a democracy? American Journal of Political Science, 48(2), 328-343.https://doi.org/10.1111/j.0092-

5853.2004.00073.x

Woodiwiss, M.(1999). Organized crime- The dumbing of discourse. Paper presented at the British Society of Criminology Conference, Liverpool, July 1999.http://www.britsoccrim.org/volume1/017.pdf

World Bank. (2020). Country profile - South Sudan. The World Bank; South Sudan. https://www.worldbank.org/en/country/southsudan/overview

Xu, J., Chen, H. (2005). Criminal network analysis and visualisation.CACM,48(6), 100-107.https://doi.org/10.1145/1064830.1064834

Young, J. (2021). South Sudan: The fractured state. In John Markakis, Günther Schlee, and John Young (Eds), The Nation State - A Wrong Model for the Horn of Africa, Studies 14, Chapter 6, pp.145-170. Berlin: Max Planck Research Library for the History and Development of Knowledge.

Zifcak, S. (2015). What happened to the international community? R2P and the conflicts in South Sudan and the Central African Republic. Melbourne Journal of International Law, 16(1),52-85. https://search.informit.org/doi/10.3316/agispt.20160771

\section{Figures}

How Significant is Organised Crime in South Sudan?
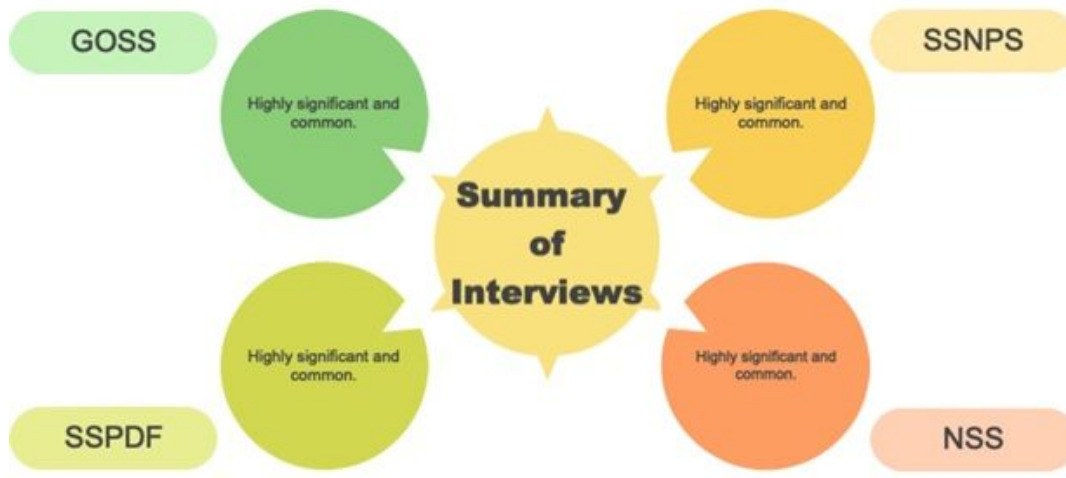

Figure. 1

\section{Figure 1}

"How significant is organised crime in South Sudan?" 


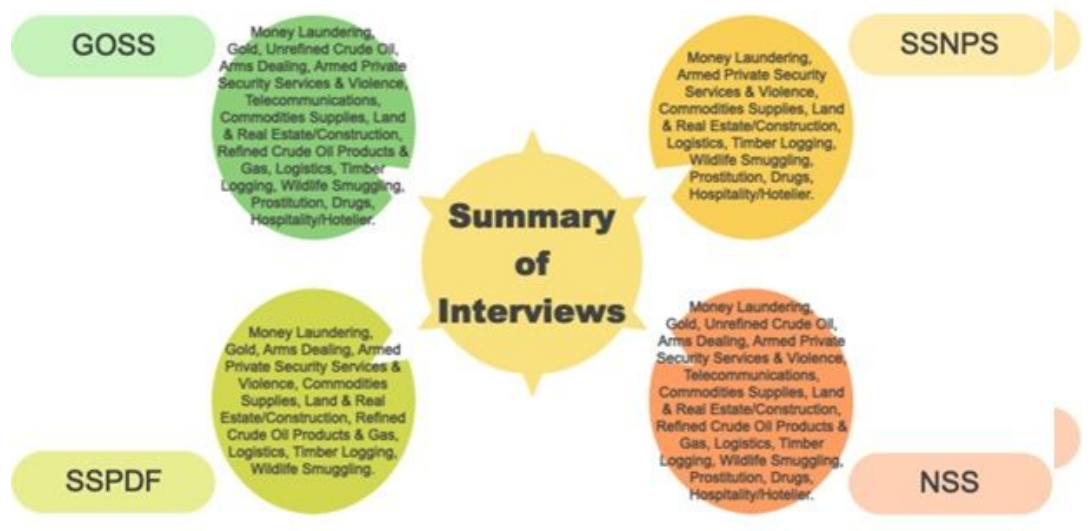

Figure. 2

\section{Figure 2}

"What is considered to be organised crime?"

Who are the Main People Engaged in Illegal \& Illicit Activities Under the Definition of Organised Crimes?

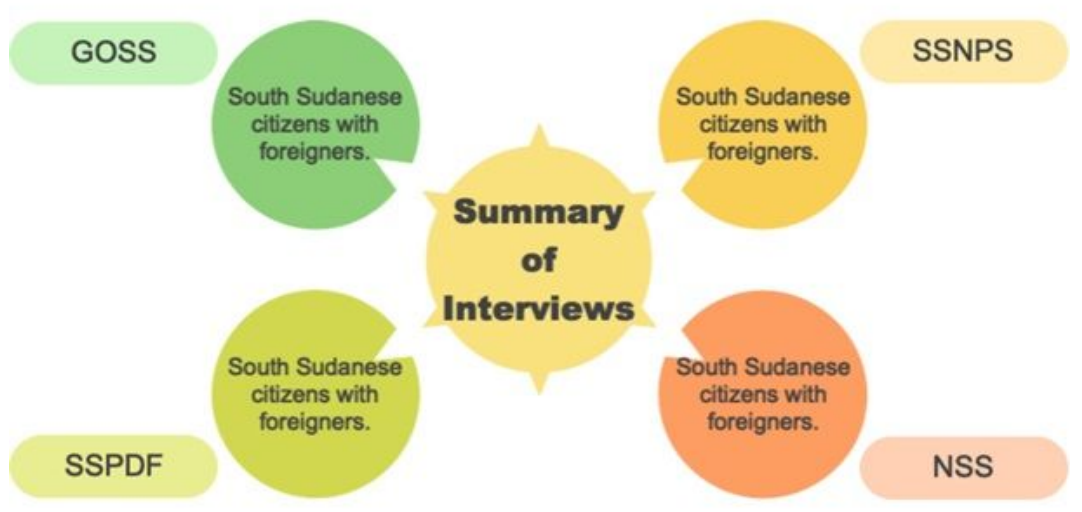

Figure. 3

\section{Figure 3}

"Who are the main people engaged in illegal and illicit activities under the definition of organised crimes?"

Which South Sudanese Political Groups, if any, Participate in

Illegal \& Illicit Activities; and When Did They Begin?

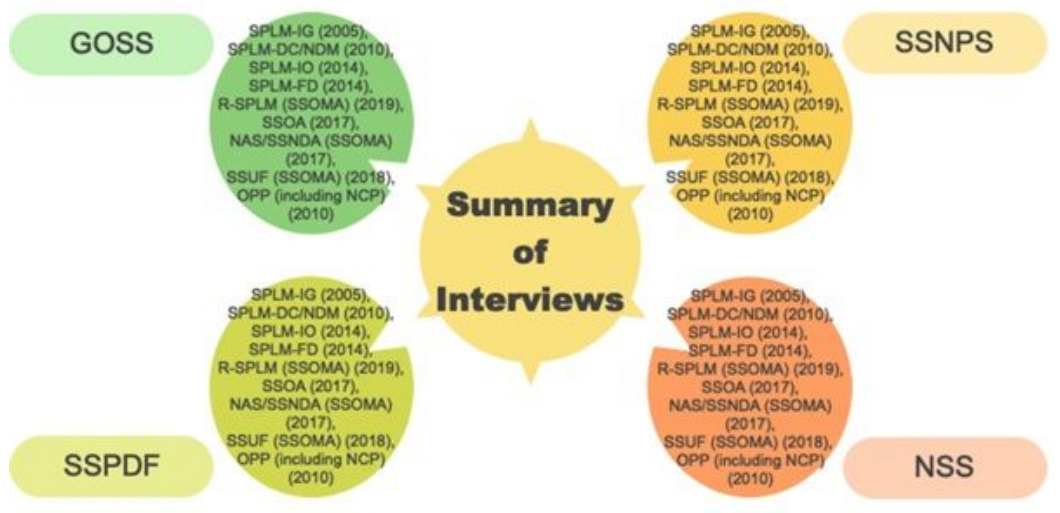

Figure. 4 
Figure 4

"Which South Sudanese political groups, if any, participate in illicit and illegal activities, and when did they begin?"

From Which Countries Do the Non-Political Organised

Groups Operating in the Country Come From?

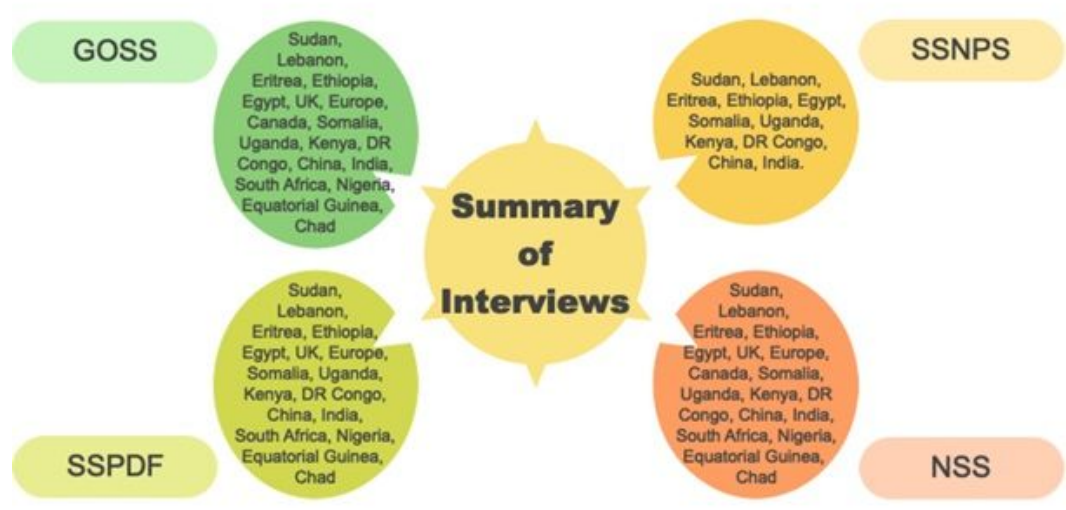

Figure. 5

\section{Figure 5}

"From which countries do the non-political organised groups operating in the country come from?"

What Kind of Illicit \& Illegal Economic Activities Do the Organised Groups Participate In?

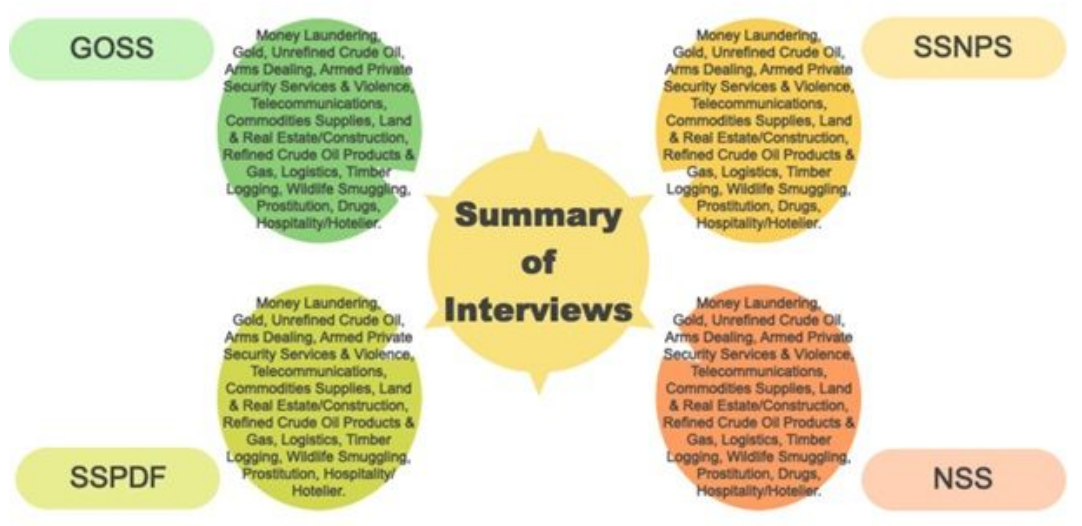

Figure. 6

Figure 6

"What kind of illicit and illegal economic activities do the organised groups participate in?" 


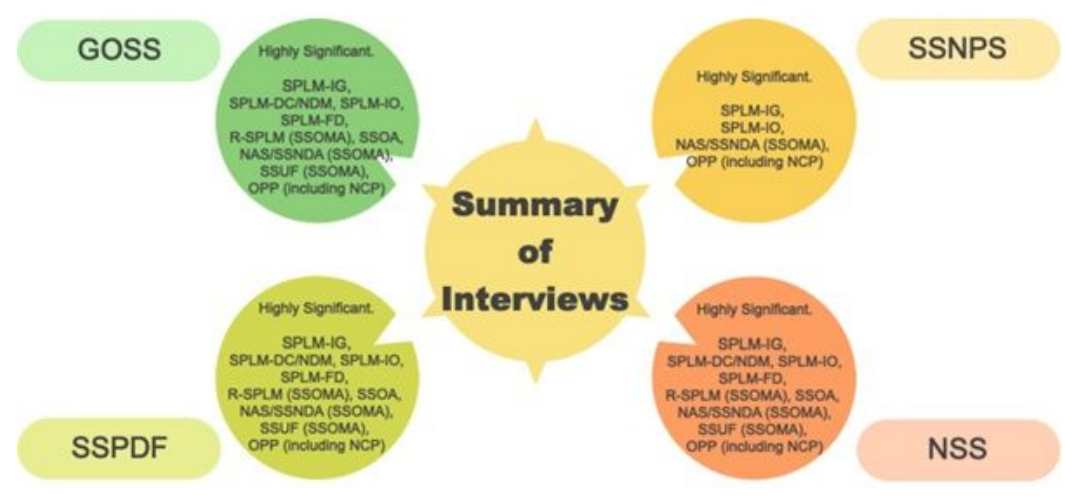

Figure. 7

\section{Figure 7}

"How significant is political corruption in facilitating organised crime? Which political groups are involved, if any?"

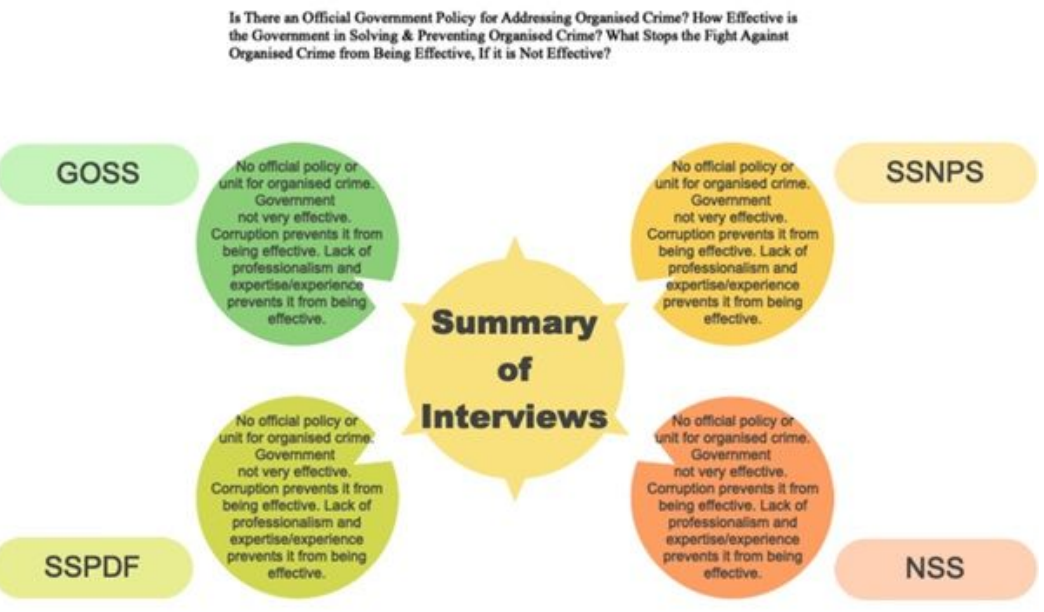

the Government in Solving \& Preventing Organised Crime? What Stops the Fight Against

Figure. 8

\section{Figure 8}

"Is there an official government policy for addressing organised crime? How effective is the government in solving and preventing organised crime? What stops the fight against organised crime from being effective, if it is not effective?" 
How Easy, or Difficult, is it to Disrupt Organised Criminal

Networks; and Why is it Hard or Easy to Do?

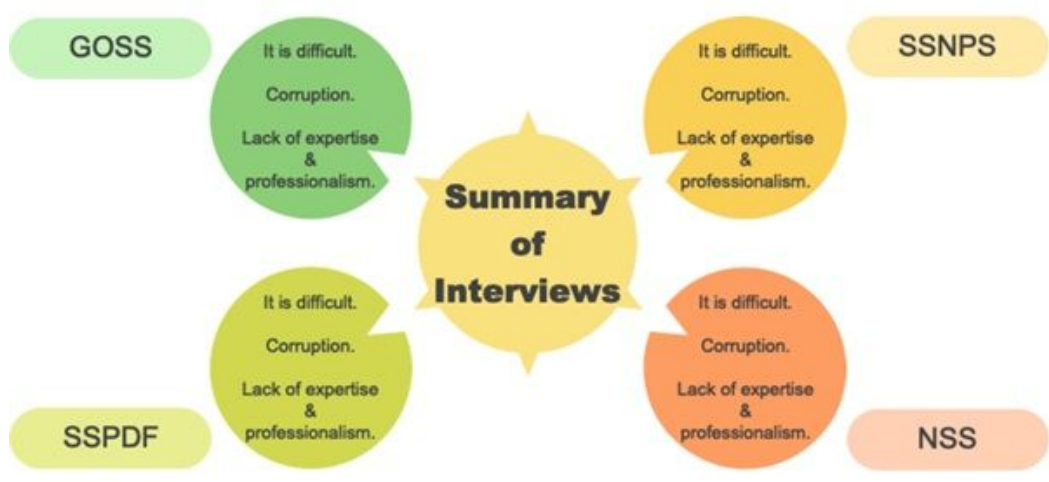

Figure. 9

Figure 9

"How easy, or difficult, is it to disrupt organised criminal networks; and why is it hard or easy to do?"

How Many Successful Prosecutions for Organised Crime Have Been Recorded Since the Country's Independence in 2011 ?

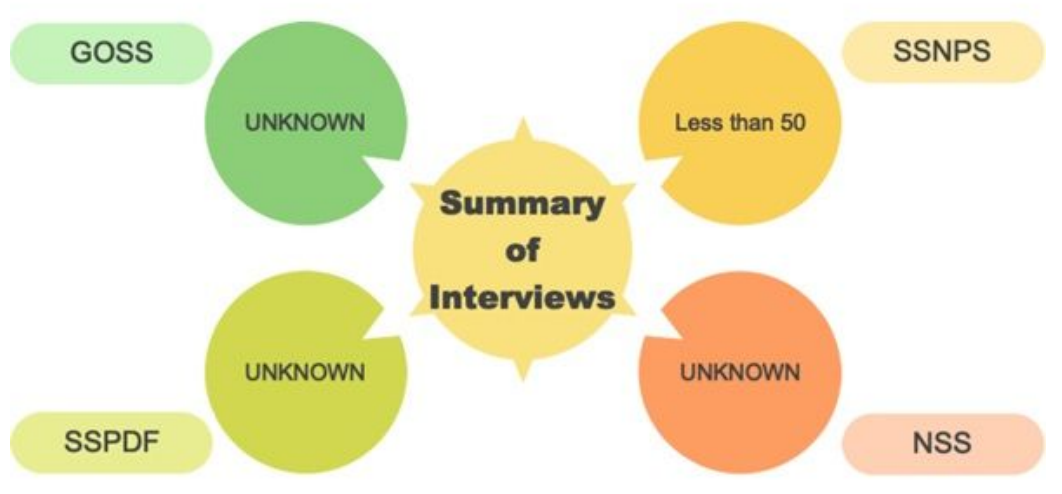

Figure. 10

\section{Figure 10}

“How many successful prosecutions for organised crime have been recorded since the country's independence in 2011?"

How Significant is Violent Crime in South Sudan?

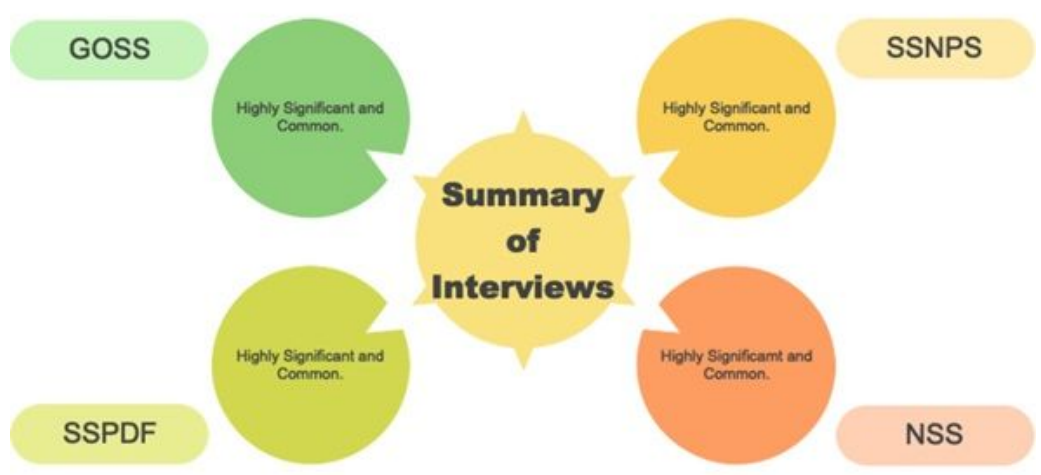

Figure. 11 
Figure 11

"How significant is violent crime in South Sudan?" Violent crime being defined as "murder", "rape", "kidnapping" or "armed robbery" (including "cattle rustling").

Is Organised Crime Associated with Violence?

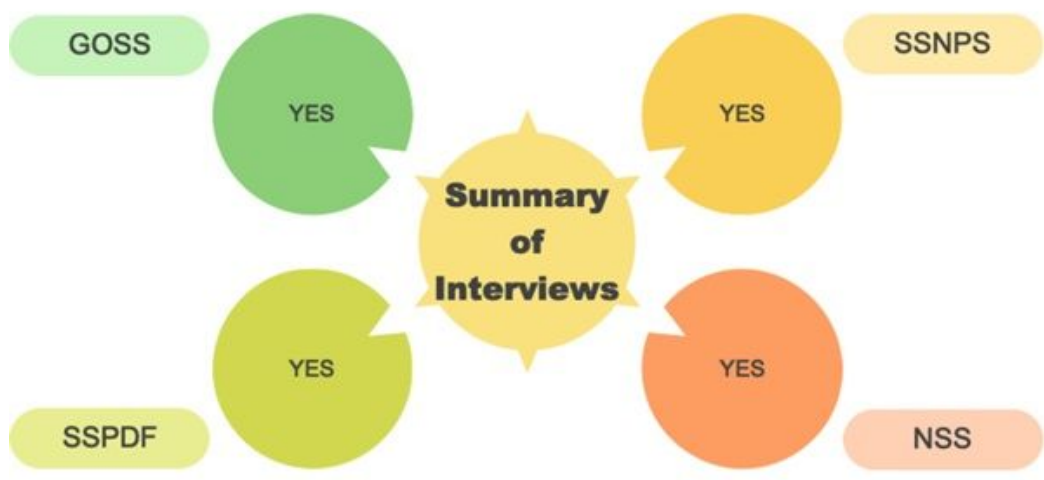

Figure. 12

\section{Figure 12}

"Is organised crime associated with violence?"

Is Religious and/or Ethnic Extremism a Significant

Component of Organised Crime?

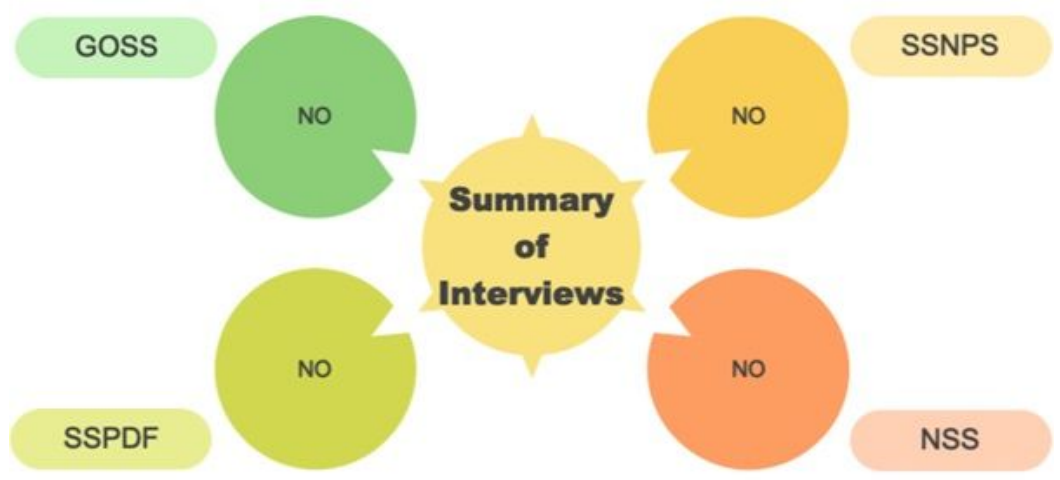

Figure. 13

\section{Figure 13}

"Is religious and/or ethnic extremism a significant component of organised crime?" 


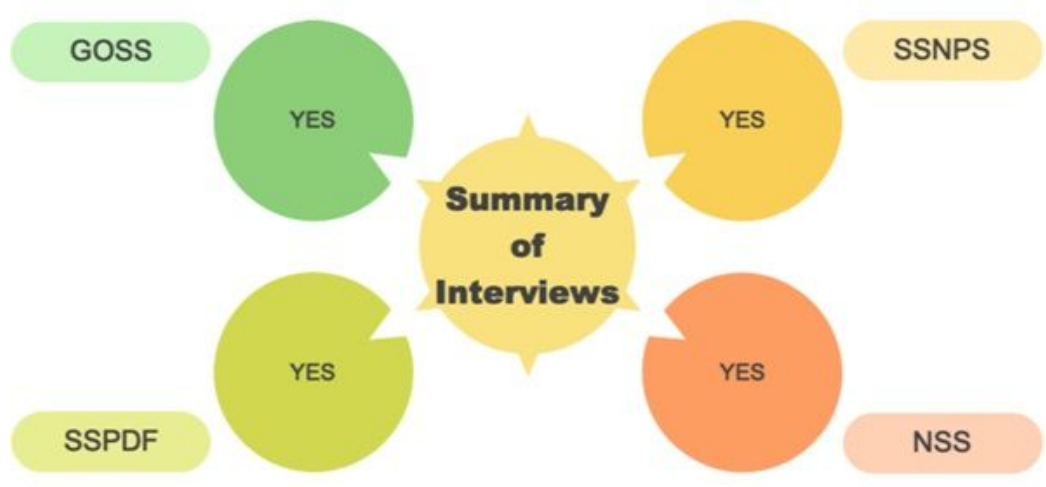

Figure. 14

\section{Figure 14}

"Do you think that there is an association between violent crime and political corruption in South Sudan?"

Do You Think That There is an Association Between Religious and/or Ethnic Extremism and Violent Crime in South Sudan?

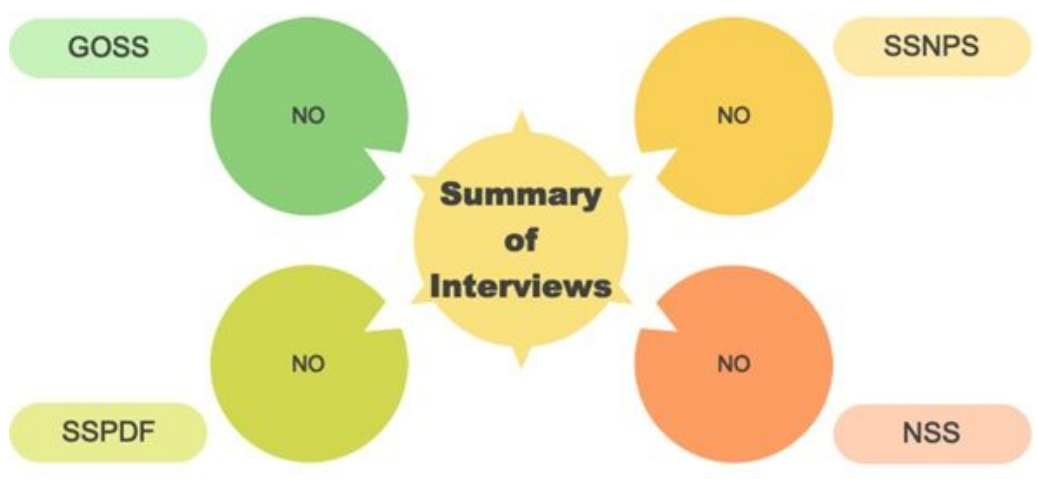

Figure. 15

\section{Figure 15}

"Do you think that there is an association between religious and/or ethnic extremism and violent crime in South Sudan?"

\section{Supplementary Files}

This is a list of supplementary files associated with this preprint. Click to download.

- EconomicSubGroupsNetworkDiagram.pdf

- PoliticalSubGroupsNetworkDiagram.pdf

- SPLMSubGroupsNetworkDiagram.pdf 